\title{
Coeur d'Alene and \\ Existential Categories for Sovereign Immunity Cases
}

\author{
Eric B. Wolff $\dagger$
}

Individuals may sue state officers in federal court according to a simple rule most closely associated with Ex Parte Young and Jordan: plaintiffs may sue for prospective relief against state officers to stop an ongoing violation of federal law or to force compliance with federal law. This rule broke down in Idaho v. Coeur d'Alene Tribe of Idaho because it fails to accurately reflect how the Court conceptualizes threats to state sovereignty worthy of immunity, as well as federal interests in providing relief. In this Comment, the author attempts to show how prevailing sovereign immunity doctrine was conceptually bankrupt in Coeur d'Alene. The author then reconstructs how the Court may have conceived of the situation in Coeur d'Alene, building upon articles by Professors Louis Jaffe and Antonin Scalia. Finally, the Comment speculates on the future of Ex Parte Young and Edelman v. Jordan after Coeur d'Alene and proposes the Court look more to legal traditions and existential categories regarding sovereign immunity, as Professor Jaffe did, rather than addressing all sovereign immunity claims with an oversimplified analytic rule.

\section{INTRODUCTION}

Much like snowflakes, no two ongoing violations of federal law by state officers are quite the same, and neither are the sovereign immunity issues that subsequently arise. Indeed, as an influential commentator observed in 1970, most sovereign immunity cases "involve unique or

Copyright (ㅇ 1998 California Law Review, Inc.

$\dagger$ B.A., 1995, Concordia College; J.D., 1998, Boalt Hall School of Law, University of California, Berkeley. I am especially grateful to Professors William Fletcher and John Dwyer for helping me with this Comment, and also to Professors Jesse Choper and Paul Mishkin for helpful insights. My interaction with these four gentlemen was the highlight of my law school education. I am also grateful to Professor Max Richardson, who introduced me to constitutional law at Concordia College and got me hooked. Finally, I want to thank my wife, Denelle, who started law school at Boalt as I began my third year. Despite all the slings and arrows of being a IL, her love and support never wavered. 
rarely recurring fact situations." However, if a plaintiff asks a federal court to stop a state officer's ongoing violation of federal law, the plaintiff faces an allegedly uniform doctrine of when state officers are and are not covered by the state's sovereign immunity. The Eleventh Amendment ${ }^{2}$ provides the States with broad immunity from suit in federal court, but the doctrine, most closely associated with Ex Parte Young ${ }^{3}$ and Edelman v. Jordan, ${ }^{4}$ holds that plaintiffs can sue state officers-as opposed to the State itself-in federal court to receive "prospective" relief from ongoing violations of federal law. Ongoing violations of federal law may differ dramatically, but the availability of prospective relief in federal court is allegedly uniform and constant. I say "allegedly" because at the doctrinal level "inconstancy and confusion [have] long characterized this field.""

After the Supreme Court's 1996 decision in Seminole Tribe v. Florida ${ }^{6}$ prominent scholars openly worried that federal courts might soon lose some of their long-held power to force state officers to comply with federal law through Ex Parte Young suits against state officers. As Professor Meltzer noted in his commentary on Seminole Tribe: "[F]ears that the Seminole decision may signal the demise of Ex Parte Young were fueled by the Court's action less than three weeks later granting the state of Idaho's petition for certiorari in Coeur d'Alene Tribe of Idaho v. State of Idaho." A noted federal courts scholar wrote of the possible "evisceration" of Ex Parte Young. ${ }^{8}$ The uniform and constant remedy of "prospective" relief in federal court seemed under attack.

A dispute between officers in a western state and an Indian tribe over possession of "[o]ne of the Nation's most beautiful lakes" could have been an epic western directed by John Ford and starring John Wayne, but instead it wound up a Supreme Court case. In Coeur d'Alene

1. Antonin Scalia, Sovereign Immunity and Nonstatutory Review of Federal Administrative Action: Some Conclusions from the Public-Lands Cases, 68 MicH. L. REv, 867, 882 (1970).

2. See infra Part II (introducing Eleventh Amendment doctrine).

3. 209 U.S. 123 (1908). Ex Parte Young is a prominent case in a long tradition of courts allowing suits against state officers even though a suit against the State itself would be barred by sovereign immunity. Ex Parte Young provided an authority-stripping rationale which holds that when a state officer is violating federal law, the officer is no longer acting on behalf of the State and the State's sovereign immunity no longer applies. See id. at 159-60.

4. 415 U.S. 651 (1974).

5. David P. Currie, Sovereign Immunity and Suits against Government Officers, 1984 SuP. CT. REv. 149, 150 (1984).

6. 116 S. Ct. 1114 (1996).

7. Daniel J. Meltzer, The Seminole Decision and State Sovereign Immunity, 1996 SuP. Cr. REv. 1, 45 (1996).

8. Vicki C. Jackson, Seminole Tribe, The Eleventh Amendment, and the Potential Evisceration of Ex Parte Young, 72 N.Y.U. L. REv. 495 (1997).

9. Idaho v. Coeur d'Alene, 117 S. Ct. 2028, 2031 (1997). 
Tribe of Idaho v. State of Idaho, a fractured majority of the Court disallowed by a 5-4 margin federal court jurisdiction over the Coeur d'Alene Tribe's claim that it, not the State of Idaho and its officers, should rightfully possess Lake Coeur d'Alene. Under what it thought to be a viable Ex Parte Young action, the Tribe claimed a federal right to sovereign authority over the Lake, a right allegedly violated by Idaho state officers. The Tribe asked only for prospective sovereignty over the Lake. The opinions of Justice Kennedy, Justice O'Connor and Justice Souter indicate that a majority of the Court chose to uphold the traditional application of Ex Parte Young, ${ }^{10}$ but a different majority disapproved of Ex Parte Young actions, such as the Tribe's, that are the functional equivalent of suits against the State. ${ }^{11}$

It is probably a mistake to treat Coeur d'Alene as representative of a broad doctrinal area. As Aristotle wisely put it, the "well-schooled" person only "searches for that degree of precision in each kind of study which the nature of the subject at hand admits." 12 Searching for a high degree of doctrinal precision in Coeur d'Alene may not be the mark of good schooling. The majority was fractured, the facts were unique, and there may be no majority vision for the future. ${ }^{13}$ Perhaps more importantly, the doctrinal tools of Ex Parte Young and Edelman v. Jordan simply did not allow for doctrinal precision in Coeur d'Alene. If we want to achieve a degree of precision regarding Coeur d'Alene, then we should try to explain the two most prominent aspects of Coeur d'Alene: (1) the Court's holding of sovereign immunity for the Idaho officials, and (2) the Court's inability to explain its holding within the existing doctrinal concepts.

Professor Jaffe's classic article, Suits against Governments and Officers: Sovereign Immunity, ${ }^{14}$ provides numerous insights into how the majority in Coeur d'Alene may have conceptualized the dispute to bolster claims of sovereign immunity and to find existing doctrinal concepts wanting. This Comment will lay out Professor Jaffe's approach and conclusions and test them against what happened in Coeur d'Alene. The key to Professor Jaffe's approach, which I will argne is also the key to understanding Coeur d'Alene, lies in dismissing abstract analytic

10. Id. at 2045 (opinion of O'Connor, J.); id. at 2048 (Souter, J., dissenting).

11. See infra note 34 .

12. Aristotle, Nichomachean Ethics 1.3 109b23-28 (Martin Ostwald ed. \& trans., 1962) ("For a well-schooled man is one who searches for that degree of precision in each kind of study which the nature of the subject at hand admits: it is obviously just as foolish to accept arguments of probability from a mathematician as to demand strict demonstrations from an orator.").

13. We might add to this list that Coeur d'Alene was argued early in the Term, October 16, and banded down late in the Term, June 23. Perhaps this timeline suggests some difficulty in finding a result, or more likely a rationale, for the decision. Perhaps not.

14. Louis L. Jaffe, Suits against Governments and Officers: Sovereign Immunity, 77 HARV. L Rev. 1 (1963). 
questions regarding sovereign immunity in favor of a pragmatic survey of sovereign immunity in the American legal tradition. ${ }^{15}$ Professor Jaffe asked: In what types of cases have courts upheld or denied sovereign immunity? He then grouped sovereign immunity cases in terms of conceptual patterns-tort cases, contract cases, and cases with significant threats to federal interests. To borrow a phrase from then-Professor Scalia, Professor Jaffe put sovereign immunity cases into "existential categories" which seemed to correspond with the likelihood of a successful sovereign immunity defense to federal court jurisdiction. ${ }^{16}$ Professor Scalia contrasted existential categories, which are fact-based, with "analytic" or "theoretical" categories. The majority in Coeur d'Alene likely conceived of the case as fitting into existential categories where immunity from suit in federal court would be the norm.

Sovereign immunity decisions like Coeur d'Alene would be far more understandable and defensible if the Court took explicit cognizance of the types of sovereign immunity legal traditions, or existential categories, identified by Professor Jaffe. Instead, the legal traditions remain implicit and the Court elects to reason with frequently bankrupt notions like "prospective" relief and to act as if all ongoing violations of federal law are the same. Because current sovereign immunity doctrine does indeed pretend to treat all ongoing violations of federal law by state officers the same, we are left with the absurd predicament that all cases invoking Ex Parte Young allegedly speak to the situation in Coeur d'Alene and that, conversely, the Court's treatment of a unique situation like Coeur d'Alene supposedly implicates all Ex Parte Young actions. As a result, virtually all Ex Parte Young doctrine is at risk of confusion or distortion in any particular case. ${ }^{17}$

Section I of this Comment introduces the Coeur d'Alene case. Section II surveys the Eleventh Amendment and the doctrines surrounding suits against state officials. In Section III, I explore the Coeur d'Alene majority's incoherent application of officer suit doctrine. Section IV introduces Professor Jaffe's analysis of American legal traditions regarding sovereign immunity and suits against officers as well as Professor Scalia's concept of "existential categories." I then test how well Coeur d'Alene coherently reflects various existential categories

15. In a similar vein, then-Professor Scalia obseryed that "case law can be understood only in the manner in which it develops," such that concepts like sovereign immunity are best understood "as containing a number of discrete, 'existential' groupings of cases whose consistency among themselves is infinitely more important ... than is their reconciliability with the mass of decisions involving the general principle." Scalia, supra note 1, at 919-20.

16. See Scalia, supra note 1, at 881-82. From this point forward 1 will refer to "Professor Scalia" when speaking about the views he expressed in his 1970 article.

17. See id. at 918-19 (discussing top down and bottom up reasoning and the risks of distortion for nonstatutory review of certain federal administrative action when starting from broad levels of generality). 
within the sovereign immunity legal tradition analyzed by Professor Jaffe, most importantly the cases involving state bond issues. Section V draws some conclusions regarding the future of Ex Parte Young in light of the opinions in Coeur d'Alene, the insights of Professor Jaffe, and the conclusions of Professor Scalia. ${ }^{18}$ Although some commentators find state sovereign immunity "deplorable" as an affront to the rule of law, ${ }^{19}$ making the decisions more coherent would at least give a rule-like bit of clarity and predictability to the immunity the Eleventh Amendment provides.

\section{I \\ The CASE}

The Coeur d'Alene Indian Tribe (the Tribe) is a federally recognized tribe with sovereign authority over the Coeur d'Alene Reservation in northern Idaho, which consists of 13,032 acres of tribal land, 55,583 acres of allotted land, and 330 Government owned acres. ${ }^{20}$ In 1991, the Tribe filed suit in federal district court against the State of Idaho, several state agencies, and various state officials in their individual capacity, claiming "the beneficial interest, subject to the trusteeship of the United States, in the beds and banks of all navigable watercourses and waters ... withm the original boundaries of the Coeur d'Alene reservation, as defined by [President Grant's] Executive Order on November 8, 1873."21 Essentially, the Tribe claimed ownership and, as a consequence, tribal sovereignty over Lake Coeur d'Alene (the Lake) in northern Idaho. ${ }^{22}$

The Tribe asked the district court to quiet title against the State with regard to the Lake. In addition, the Tribe

sought a declaratory judgment to establish its entitlement to the exclusive use and occupancy and the right to quiet enjoyment of

18. See Scalia, supra note 1.

19. David P. Currie, Ex Parte Young After Seminole Tribe, 72 N.Y.U. L. Rev. 547, 548 (1997). Although Professor Currie finds sovereign immunity a "rotten idea," he also counsels that "if the Constitution is defective it should be amended, not ignored; twisting the Constitution is not good for the rule of law." Id.

20. See Idaho v. Coeur d'Alene, 117 S. Ct. 2028, 2032 (1997).

21. Id. The Tribe included in its claim that President Grant's Executive Order of 1873 was ratified by Congress in 1891. Coeur d'Alene Tribe of Idaho v. Idaho, 42 F.3d 1244 (9th Cir. 1994).

22. Justice Kennedy describes Lake Coeur d'Alene as follows:

In the northern region of Idaho, close by the Coeur d'Alene Mountains which are part of Bitterroot Range, lies tranquil Lake Coeur d'Alene. One of the Nation's most beautiful lakes, it is some 24 miles long and 1 to 3 miles wide. The Spokane River originates here and thence fiows west, while the Lake in turn is fed by other rivers and streams, including Coeur d'Alene River which fiows to it from the east, as does the forested Saint Joe River which begins high in the Bitterroots and gathers their waters along its 130-mile journey. To the south of the lake lies the more populated part of the Coeur d'Alene Reservation.

117 S. Ct. at 2031. 
the submerged lands as well as a declaration of the invalidity of all Idaho statutes, ordinances, regulations, customs or usages which purport to regulate, authorize, use or affect in any way the submerged lands. ${ }^{23}$

More importantly, the Tribe sought injunctive relief to stop all current and future violations of its federal right, pursuant to President Grant's executive order, to own and possess Lake Coeur d'Alene. All of the defendants answered the Tribe's complaint with a 12(b) motion to dismiss, arguing that the Tribe's action was barred by the Eleventh Amendment of the United States Constitution which gives the States general sovereign immunity from suit in federal court. Idaho also claimed ownership of the Lake under the "equal footing" doctrine, which provides in part that the federal government holds submerged lands in trust for future States to be granted to new States entering the Union so that they may have sovereignty on an "equal footing" with sister States.

\section{A. The District Court Decision}

The federal district court upheld the State's Eleventh Amendment defense for both the State and its officers. ${ }^{24}$ The district judge held that the State was immune from the quiet title action and that this immunity also covered the state officers because "the declaratory relief sought by the Tribe [against the officers] would have the same effect as an award of damages or restitution by the court, which is not allowed under the Eleventh Amendment."2s Although the finding of immunity for all the defendants precluded the Tribe's suit, the court alternatively made a finding that the Tribe's possessory claims were "without foundation"26 so that even if a suit for prospective compliance with federal law could proceed under Ex Parte Young, the Tribe would not succeed.

\section{B. The Ninth Circuit Decision}

The Ninth Circuit affirmed in part, with respect to suit against the State, but reversed in part, allowing suit against the state officers, and ruling that the State did not possess the disputed lands as a matter of law. ${ }^{27}$ The panel upheld Eleventh Amendment immunity for the State,

\footnotetext{
23. Id. at 2032.

24. See Coeur d'Alene Tribe of Idaho v. Idaho, 798 F. Supp. 1443 (D. Idaho 1992).

25. Id. at 1448 (emphasis omitted).

26. See id. at 1449. The district court found that the 1873 "agreements with the Coeur d'Alene Tribe made no express conveyance of the beds and banks of navigable waters within the reservation, or any other references which could be construed as having done so." Id. at 1451. Thus, the Tribe was unable to overcome "the strong presumption that these lands were held in trust by the United States and conveyed to the State of Idaho upon its admission to the Union on an 'equal footing' with the other states." Id. at 1451-52.
}

27. See Coeur d'Alene Tribe of Idaho v. Idaho, 42 F.3d 1244 (9th Cir. 1994). 
finding that the State had not consented to quiet title actions in federal court. $^{28}$ The panel found no immunity, however, from an Ex Parte Young action for state officers. Relying on Supreme Court precedent allowing suits involving rights to property to proceed against officers so long as title is never quieted with respect to the State itself, ${ }^{29}$ the panel stated: "[I]f the district court finds that the property at issue belongs to the Tribe pursuant to federal law, it may decree the Tribe to be the owner of the property against all claimants except the State of Idaho and its agencies." 30 The court recognized that such a resolution of the officer suit would mean that neither the State nor the Tribe would have "unclouded title to the property," but the court would not "refuse to enforce the federal rights of Indian tribes against action by state officials merely because we cannot afford them complete relief."31 The panel then reversed the district court's finding that the State possessed the Lake as a matter of law. ${ }^{32}$

\section{The Supreme Court Decision}

In a 5-4 decision, the Supreme Court reversed the Ninth Circuit, ruling that the Tribe could not proceed against the state officers in federal court under Ex Parte Young. ${ }^{33}$ The Court's majority was split. Justice Kennedy wrote an opinion joined by Chief Justice Rehnquist, and Justice $O^{\prime}$ Connor wrote a separate opinion joined by Justices Scalia and Thomas. All five Justices agreed that the Tribe's suit could not proceed because it was the "functional equivalent" of a suit against the

28. See id. at 1249-50. The Tribe had three arguments as to consent: (1) Idaho courts had interpreted the common law so as to allow quiet title actions against the State in state courts; (2) Idaho's constitution disclaimed any interest in Indian lands; (3) Idaho had conceded to the federal government's absolute jurisdiction over Indian lands. These arguments were dismissed accordiugly: (1) consent to suit in state court is not coextensive with consent to suit in federal court; (2) other states have similar provisions that the courts have not held to be consent; (3) Idaho consented merely to suit by the U.S. regarding Indian lands, not suits by Indian tribes, as the Supreme Court determined in Blatchford $v$. Village of Noatak, 501 U.S. 775, 784-86 (1991).

29. See id. at 1250-55. The Ninth Circuit relied primarily on two cases involving officer suits and property: Tindal v. Wesley, 167 U.S. 137 (1897) (allowing action for possession of property held by state officers of South Carolina where the State had seized the property without affording due process or just compensation); Florida Dep't of State v. Treasure Salvors, Inc., 458 U.S. 670 (1982) (allowing plaintiffs with an Ex Parte Young action to recover possession of artifacts found on federal property and in the wrongful possession of state officers). These cases are discussed extensively below. See infra notes 101-09 and accompanying text.

30. 42 F.3d at 1255.

31. Id.

32. See id, at 1255-57. The Ninth Circuit held that the district court erred in its search for language in the 1873 agreement that could be a "reservation" of iuterest in submerged land, and that the President could convey lands such as Lake Coeur d'Alene to Indian tribes without prior express congressional authorization. Id. at 1256-57.

33. See ldaho v. Coeur d'Alene, 117 S. Ct. 2028 (1997). 
State. ${ }^{34}$ Justice Kennedy, however, called for a reformulation of Ex Parte Young that would give state courts a much greater role in adjudicating federal claims against state officers. Justice Souter dissented, joined by the remaining three Justices, arguing that the Tribe's suit could proceed under the standard application of Ex Parte Young as a suit forcing prospective compliance with federal law.

\section{II}

\section{The Eleventh Amendment and Officer Suits}

\section{A. States May Not Be Sued in Federal Court without Either Consent or Congressional Abrogation}

There are inherent qualities of sovereignty, and one of the most fundamental might be that "[t]he King cannot be sued without his consent." ${ }^{35}$ Indeed, Alexander Hamilton wrote that "[i]t is inherent in the nature of sovereiguty, not to be amenable to the suit of an individual without [the State's] consent," ${ }^{36}$ and James Madison similarly stated that "[i]t is not in the power of individuals to call any state into court." The State of Idaho's immunity to suit in federal court surely begins with these inherent qualities of sovereignty, but these principles have been interpreted through the Eleventh Amendment. Although the text of the Eleventh Amendment reflects but a small measure of the immunity it provides in its application, it is nonetheless important to appreciate current doctrine fully. The Amendment states:

The Judicial power of the United States shall not be construed to extend to any suit in law or equity, commenced or prosecuted against one of the United States by Citizens of another State, or by Citizens or Subjects of any Foreign State. ${ }^{38}$

34. See id. at 2040 (opinion of Kennedy, J.) ("[T] he declaratory and injunctive relief the Tribe seeks is close to the functional equivalent of quiet title in that substantially all benefits of ownership and control would shift from the State to the Tribe."); id. at 2043 (opinion of O'Connor, J.) ("“A]s the Tribe concedes, the suit is the functional equivalent of an action to quiet its title to the bed of Lake Coeur d'Alene.").

35. Jaffe, supra note 14 , at 1 .

36. THE FederalisT No. 81, 548-49 (J. Cooke ed. 196I).

37. Jonathan Elliot, The Debates in the Several State Conventions on the Adoption of the Federal Constrtution 533 (2d ed. 1863). See also Blatchford v. Native Village of Noatak, 501 U.S. 775,780 (1990).

38. U.S. CoNST. amend. XI. Then-Justice Rehnquist described in Edelman v. Jordan, 415 U.S. 651, 660 (1974), the historical basis of the Eleventh Amendment as "one of the more dramatic examples of this Court's effort to derive meaning from the document given to the Nation by the Framers nearly 200 years ago." The drama stems from the fact that the Eleventh Amendment was adopted to directly overturn a Supreme Court decision. As Professor William Fletcher explains:

Everyone agrees that the Eleventh Amendment was adopted to overturn the result the Supreme Court reached in Chisholm v. Georgia [2 U.S. (2 Dall.) 419] in 1793. The plaintiff in Chisholm was a citizen of South Carolina who had sued the State of Georgia on a contract in a common law assumpsit action. The suit was brought in the original jurisdiction of the Supreme Court. The source of jurisdiction was the provision in Article IlI of the 
By "Judicial power," the Amendment refers to the power of federal courts in Article III. The plain language of the Amendment therefore seems to limit the extent of federal judicial power under Article III, much as it limits subject matter jurisdiction in federal courts. However, unlike subject matter jurisdiction, a state can waive its sovereign immunity to suit in federal court and thereby "cure" what seems an Article III defect. . $^{39}$

Judicial interpretations of the Eleventh Amendment, particularly Hans $v$. Louisian $a{ }^{40}$ have produced an immunity far beyond the text of the Amendment. The Court has "understood the Eleventh Amendment to stand not so much for what it says, but for the presupposition of our constitutional structure which it confirms: that the States entered the federal system with their sovereignty intact; that the judicial authority in Article III is limited by this sovereignty." ${ }^{31}$ Although the text of the Eleventh Amendment would only seem to immunize a state from suit in federal court by non-state citizens, the Court held in Hans that the Eleventh Amendment barred a federal constitutional claim by a Louisiana citizen against the State of Louisiana in federal court. Hans therefore significantly broadened the range of parties incapable of suing a state in federal court.

Since Hans, the presuppositions of Eleventh Amendment sovereign immunity, rather than the text of the Amendment, have barred suits against states in federal court involving admiralty claims, ${ }^{42}$ suits by foreign sovereigns, ${ }^{43}$ and most siguificant to Coeur d'Alene, suits by Indian tribes. ${ }^{44}$ Congress may abrogate Eleventh Amendment immunity and

United States Constitution extending the federal judicial power to

"controversies... between a State and Citizens of another State," and a possibly unnecessary parallel provision in $\S 13$ of the Judiciary Act of 1789. The Supreme Court in Chisholm construed the Article 111 provision to mean that it had jurisdiction to hear Chisholm's damage action against Georgia, and held by a four to one vote than any sovereign immunity defense the state might other wise have had was thereby abrogated.

The Eleventh Amendment overruled the Court's decision in Chisholm ....

William A. Fletcher, The Diversity Explanation of the Eleventh Amendment: A Reply to Critics, 56 U. CHI. L. REV. 1261, 1263-64 (1989). It should be noted that the surge to overrule Chisholm started the day after the decision was announced when "Representative Theodore Sedgwick of Massachusetts introduced a proposed amendment in the House that would have flatly prohibited a state from being made a defendant in a suit brought by a private individual." Id. at 1269 . With several modiflcations, the Eleventh Amendment was eventually ratifled in 1795.

39. See Idaho v. Coeur d'Alene, 117 S. Ct. at 2033 (1997).

40. 134 U.S. 1 (1890).

41. Blatchford v. Native Village of Noatak, 501 U.S. 775, 779 (1991) (citations omitted).

42. See In re New York, 256 U.S. 490 (1921).

43. See Principality of Monaco v. Mississippi, 292 U.S. 313 (1934).

44. See Blatchford, 510 U.S. 775. In Blatchford, a tribe brought an Equal Protection claim in federal court charging that the State of Alaska had wrongfully withheld benefits. The tribe asked for monies that would have been received but for the unconstitutional action. The tribe claimed that established sovereign immunity doctrine did not bar the suit because it was not an instance of an individual suing a sovereign, but rather, a sovereign suing a sovereign. The Court held that the States 
allow states to be sued in federal court, but only if Congress acts pursuant to its power to enforce the Fourteenth Amendment. ${ }^{45}$ In addition, Congress might be able to overcome the Eleventh Amendment by making states subject to suit in state courts. Prior to Seminole Tribe, "many scholars had concluded" that the Court had "definitively embraced" a "forum-allocation interpretation of the Eleventh Amendment," which would allow Congress to make states subject to federal causes of action in state courts, even if the Eleventh Amendment might bar such federal causes of action in federal court. ${ }^{46}$ The viability of a forum-allocation interpretation may have divided the Coeur d'Alene majority. ${ }^{47}$ Finally, the Eleventh Amendment does not apply if the United States or another state sues a state. ${ }^{48}$

had not consented to suits by Indian tribes in the adoption of the Constitution and that Congress had not abrogated the States' immunity to such suits.

45. See Seminole Tribe of Florida v. Florida, 116 S. C. 1114 (1996). Seminole Tribe overruled Pennsylvania v. Union Gas Co., 491 U.S. 1 (1989), in which a plurality of the Court found that the Commerce Clause "granted Congress the power to abrogate state sovereign immunity, stating that the power to regnlate interstate commerce would be incomplete without the authority to render States liable in damages." Id. at 1125 . The Court in Seminole Tribe stated:

In overnuling Union Gas today, we reconfirm that the background principle of state sovereign immunity embodied in the Eleventh Amendment is not so ephemeral as to dissipate when the subject of the suit is an area, like the regulation of Indian commerce, that is under the exclusive control of the Federal Government. Even when the Constitution vests in Congress complete lawmaking authority over a particular area, the Eleventh Amendment prevents congressional authorization of suits by private parties against unconsenting States. The Eleventh Amendment restricts the judicial power under Article III, and Article I cannot be used to circumvent the constitutional limitations placed upon federal jurisdiction.

Id. at 1131-32.

The Court has held that Congress can only abrogate state sovereign immunity to suit in federal court if Congress is acting pursuant to $\S 5$ of the Fourteenth Amendment. See Fitzpatrick v. Bitzer, 427 U.S. 445 (1976). In Fitzpatrick, the Court recognized that "the Fourteenth Amendment, by expanding federal power at the expense of state autonomy, had fundamentally altered the balance of state and federal power struck by the Constitution." Seminole Tribe, $116 \mathrm{~S}$. C. at 1125.1 is worth noting that since Seminole Tribe restricted abrogation power under Article I, City of Boerne v. Flores, 117 S. Ct. 2157 (1997), although not an Eleventh Amendment case, significantly restricts the powers of Congress under $\S 5$ of the Fourteenth Amendment and this correspondingly restricts the power of Congress to abrogate state sovereign immunity to suit in federal court.

46. See Carlos M. Vazquez, What Is Eleventh Amendment Immunity?, 106 Yale LJ. 1683, 1689 (1997). The key cases supporting the "forum-allocation interpretation" are McKesson Corp. v. Dep't of Alcoholic Beverages \& Tobacco, 496 U.S. 18 (1990), Hilton v. South Carolina Pub. Ry. Comm'n, 502 U.S. 197 (1991), and Reich v. Collins, 115 S. Ct. 547 (1994).

47. See infra Part V.B.

48. In fact, the United States has sued Idaho on behalf of the Coeur d'Alene Tribe in federal district court. See United States v. Idaho, No. 94-0328 (D. Idaho filed July 21, 1994); 117 S. Ct. at 2033. It is important to note that the Court knew the U.S. had filed on behalf of the Tribe when the Court heard the case. Although the claims the U.S. made for the Tribe were more modest than what the Tribe sought in its own lawsuit, the Court knew when it decided Coeur d'Alene that it was not entirely depriving the Tribo of a federal forum in this matter. 


\section{B. State Officers Are Subject to Federal Claims in Federal Court for "Prospective" Relief}

In England, "the King [could not] be sued without his consent," but the doctrine of sovereign immunity never had "much impact on the judicial control of administrative illegality."49 Likewise, the States have broad immunity in the United States, but state officers are generally amenable to suit in federal court. Although officer suits existed before Ex Parte Young, the Young case provided an important and oft-cited rationale for evading Eleventh Amendment immunity: when a state officer acts in violation of federal law, the officer is no longer acting on behalf of the State and the State's sovereign immunity no longer applies. $^{50}$ The two most important restrictions on Ex Parte Young actions are the limits to prospective relief and federal causes of action.

State officials are stripped of state authority, and also state immunity, when they are in violation of federal law. In Young, an action was brought against the Minnesota Attorney General to enjoin the enforcement of an allegedly unconstitutional state statute in a Minnesota state court. The Attorney General claimed that suit against him was an action against the State, but the Court held that a state officer acting unconstitutionally did not comprise state action for purposes of the Eleventh Amendment. ${ }^{51}$ This fiction creates a "well-recognized irony," making "unconstitutional conduct by a state officer... 'state action' for purposes of the Fourteenth Amendment yet not attributable to the State for purposes of the Eleventh." 52 Kenneth Culp Davis saw Ex Parte Young not so much as ironic, but as disingenuous. He humorously described the typical officer suit as follows:

49. Jaffe, supra note 14, at 2.

50. See Ex Parte Young, 209 U.S. 123, 159-60 (1908). This rationale also works for suits against federal officials and "rationalization has proceeded in terms of an abstract sovereign equally applicable to both [state and federal cases]." Jaffe, supra note 14, at 23 . The history of officer suits, including Coeur d'Alene, has proceeded with cross-citing of federal and state immunity cases.

51. See 209 U.S. at 159-60. Explaining the fiction, the Court stated:

The act to be enforced is alleged to be unconstitutional, and if it be so, the use of the name of the State to enforce an unconstitutional act to the injury of complainants is a proceeding without the authority of and one which does not affect the State in its sovereign or govemmental capacity. 1t is simply an illegal act upon the part of a state official in attempting by the use of the name of the State to enforce a legislative enactment which is void because unconstitutional. If the act which the state Attomey General sceks to enforce be a violation of the Federal Constitution, the officer in procceding under such enactment comes into confiict with the superior authority of that Constitution, and he is in that case stripped of his official or representative character and is subjected in his person to the consequences of his individual conduct. The State has no power to impart to him any immunity from responsibility to the supreme authority of the United States.

Id.

52. Florida Dep't of State v. Treasure Salvors, Inc., 458 U.S. 670, 685 (1982) (opinion of Stevens, J.). 
You may get relief against the sovereign if, but only if, you falsely pretend that you are not asking for relief against the sovereign. The judges often will falsely pretend that they are not giving you relief against the sovereign, even though you know and they know, and they know that you know, that the relief is against the sovereign. Even when the substance of sovereign inmunity is gone, the form usually remains. The courts do not violate the doctrine of sovereign immunity except in substance. ${ }^{53}$

In many ways, Ex Parte Young "squarely contradicts" the sovereign immunity recognized by a decision like Hans $v$. Louisiana. ${ }^{54}$

Officer suits, however, are subject to limitations. Ex Parte Young actions are only allowed when a plaintiff asks for prospective relief to end a state officer's ongoing violation of federal law or to compel compliance with federal law. ${ }^{55}$ Ex Parte Young does not allow retrospective relief to remedy past violations of federal law..$^{56}$ Edelman $v$. Jordan initiated a prospective/retrospective inquiry as a doctrinal natter to provide an analytic framework for limits on Ex Parte Young relief. In Edelman, the plaintiffs alleged that the State of Illinois had not adhered to federal regulations in administering the Aid to the Aged, Blind, or Disabled program. As a result, the plaintiffs had been improperly without benefits, soine for several months. They asked the federal district court to enjoin the Illinois officials to comply with the federal regnlations and also to award the benefits they should have received.$^{57}$ It was conceded that Ex Parte Young allowed for an injunction requiring future administrative compliance, ${ }^{58}$ but the Court denied the award of unreceived past benefits. The Court quoted from Ford Motor Co. v. Department of Treasury" that "when the action is in essence one for the recovery of money from the state, the state is the real, substantial party in interest and is entitled to invoke its sovereign immunity from suit even though individual officials are nominal defendants." 60 The Court then contrasted Ford Motor Co. with Ex Parte Young and concluded that the award of past benefits was more like Ford Motor Co. than the negative injunction at issue in Ex Parte Young. ${ }^{61}$

The Court in Edelman admitted that the prospective/retrospective distinction was not like "that between day and night" because many

53. Kenneth C. Davis, Suing the Government by Falsely Pretending to Sue an Officer, $29 \mathrm{U}$. CH. L. Rev. 435 (1962).

54. See Currie, supra note 19 , at 547 (1997).

55. See Milliken v. Bradley, 433 U.S. 267, 289-90 (1977).

56. See Edelman v. Jordan, 415 U.S. 651,668 (1974).

57. See id. at 653-56.

58. See id. at 664 .

59. 323 U.S. 459 (1945).

60. Id. at 464 .

61. See Edelman, 415 U.S. at 665 . 
prospective injunctions will have high compliance costs paid from the State's treasury. ${ }^{62}$ The prototypical "prospective" remedy can be found in Ex Parte Young itself-a negative injunction prohibiting a state official from undertaking a specific action. The prototypical "retrospective" remedy would be the remedy denied in Edelman-any remedy resembling damages, restitution, or other money paid for past harms. Since Edelman, the Court has held fast to the prospective/retrospective line even where it seems an unhelpful analytic framework, such as in Milliken v. Bradley (II). ${ }^{63}$ In Milliken (II), a school desegregation case, a federal court "effectively ordered the state of Michigan to pay half the cost of compensatory educational programs as part of the remedy for past unconstitutional segregation." ${ }^{164}$ Faced with the prospective/retrospective limits of Edelman, the Court made a brief, unconvincing argument that the remedy was prospective: "[The programs] are part of a plan that operates prospectively to bring about the delayed benefits of a unitary school system." ${ }^{65}$ Without the aid of time travel, it would be impossible for a court to order anything that would not at least operate prospectively. ${ }^{66}$ Similarly, the Court has held that some types of relief may draw on the state treasury but be "ancillary" to an otherwise prospective remedy, such as an award of attorneys' fees $^{67}$ or notice to a class of beneficiaries of prospective relief. ${ }^{68} \mathrm{Al}-$ though the prospective/retrospective distinction as applied by the Court often collapses, it remains the key doctrinal limit on Ex Parte Young actions.

The interest of state sovereiguty imposes a second limitation on $E x$ Parte Young actions. The authority-stripping rationale of Ex Parte Young would seem to apply to state officials alleged to be in violation of either state or federal laws. Nonetheless, a 5-4 majority of the Court held in Pennhurst State School \& Hospital v. Halderman ${ }^{69}$ that federal courts are barred by the Eleventh Amendment from hearing Ex Parte Young claims based on alleged violations of state law, even as a matter of pendent jurisdiction with a federal action. The Court found that the

\footnotetext{
62. See id. at 667 .

63. 433 U.S. 267, 289-90 (1977).

64. Richard H. Fallon, Jr., The Ideologies of Federal Courts Law, 74 VA. L. REv. 1141, 1198

65. Milliken, 433 U.S. at 290 (emphasis in original).

66. As Professor William Fletcher explained the prospective/retrospective analysis of Milliken
} (1988). (II), the Court engaged in "sleight of hand" because "in the sense used by the Court even a simple order to pay money damages operates prospectively." William A. Fletcher, A Historical Interpretation of the Eleventh Amendment: A Narrow Construction of an Affirmative Grant of Jurisdiction Rather than a Prohibition Against Jurisdiction, 35 STAN. L. REV. 1033, 1122 (1983). See also Currie, supra note 5, at 162 ("[N]obody is ever ordered to have paid yesterday.").

67. See Hutto v. Finney, 437 U.S. 678 (1978).

68. See Quem v. Jordan, 440 U.S. 332 (1979).

69. 465 U.S. 89 (1984). 
"intrusion on state sovereignty [is greatest] when a federal court instructs state officials on how to conform their conduct to state law." Pennhurst ensured that "state courts alone will interpret state law and devise and implement corresponding institutional remedies." Aft After Pennhurst, Ex Parte Young actions can only be brought in federal court regarding alleged violations of federal law.

\section{III}

\section{OfFICER SUIT Doctrine IN Coeur d'Alene}

By a 5-4 margin the Court held that the Eleventh Amendment prevented the Tribe from maintaining an Ex Parte Young action in federal court to acquire prospective sovereignty over the Lake. A majority clearly retained the prospective/retrospective standard of Edelman, but it was entirely unclear whether the prospective/retrospective test had anything to do with the Court's dismissal of the Tribe's Ex Parte Young suit. In addition, it is unclear whether the Court supplemented the prospective/retrospective test with a "functional equivalent" test. Under a functional equivalent test, even prospective relief would be barred should the Court find that relief the "functional equivalent" of a suit against the State. The test of Edelman was that retrospective relief makes the State the real party in interest. Coeur d'Alene may hold that a certain type of action may raise the saine sovereign immunity concerns as retrospective relief, even if the relief is not technically retrospective. The following sections summarize the three opinions in Coeur d'Alene and then delve into particular doctrinal issues regarding the varying prospective/retrospective analyses, the "functional equivalent" standard, and Justice Kennedy's proposal to balance state and federal interests.

\section{A. Summary of the Opinions}

Justice Kennedy and Chief Justice Rehnquist. Justice Kennedy and Chief Justice Rehnquist advocated a full scale reformulation of Ex Parte Young: when a state forum is available, federal courts should engage in case-by-case balancing of state interests against the nature and importance of the federal right at issue and any "special factors counseling hesitation."72 Justice Kennedy did not so much make a compelling doctrinal argnment for this balancing approach, as he frankly admitted that the absence of a state forum was not the "doctrinal basis" for early

70. Id. at 106.

71. John P. Dwyer, Pendent Jurisdiction and the Eleventh Amendment, 75 CALIF. L. Rev. 129, 130 (1987).

72. Idaho v. Coeur d'Alene, 117 S. Ct. 2028, 2035-43 (1997) (opinion of Kennedy, J.). The reference to "special factors counselhing hesitation" is drawn from Bivens v. Six Unknown Fed. Narcotics Agents, 403 U.S. 388, 396 (1971), and Schweiker v. Chilicky, 487 U.S. 412 (1988). 
cases allowing officer suits in federal court. ${ }^{73}$ Rather, Justice Kennedy emphasized state interests in having a state foruin, ${ }^{74}$ the coinpetence of state courts, ${ }^{75}$ and the availability of a federal forum when it has an "indispensable" role to play in the constitutional system. ${ }^{76}$ Justice Kennedy did not provide an exhaustive list of instances when federal courts might be "indispensable." He thought federal courts were preferable to preserve the "structural integrity of the constitutional design," " such as when a State sues a sister State or the United States sues a State. Justice Kennedy also believed that the "substantive provisions of the Fourteenth Amendinent themselves offer a powerful reason to provide a federal forum."78 Justice Kennedy's position would possibly leave to state courts a vast array of Ex Parte Young suits based on nonconstitutional federal claims, such as the Americans With Disabilities Act, the Fair Labor Standards Act, or Title VII-causes of action outside the short list offered by Justice Kennedy of when federal courts are "indispensable."

Justice Kennedy's opinion is a classic "Federalist" opinion where "states emerge as sovereign entities against which federal courts should exercise only limited powers, and state courts ... are presumed to be as fair and competent as federal courts."'79 Indeed, Justice Kennedy's opinion is remiuiscent of the first Justice Harlan's dissent in Ex Parte Young, where Justice Harlan argued that "[w]e must assume-a decent respect for the States requires us to assume-that the state courts will enforce every right secured by the Constitution." 80 The general theme of Justice Kennedy's opinion is that state interests ought to be reflected in Ex Parte Young doctrine because the State is always an interested party: "[T]he Young fiction is an exercise in line-drawing. There is no reason why the line cannot be drawn to reflect the real interests of States consistent with the clarity and certainty appropriate to the Eleventh Amendment's jurisdictional inquiry." ${ }^{21}$ In performing his balancing

73. See id. at 2035 ("In these early cases, the Court, although expressing concern over the lack of a forum, did not rely on the lack of a forum as its doctrinal basis.").

74. See id. at 2036, 2037-38 (noting the state courts' "vital" interest in integrating federal law into "their own system for the proper judicial control of state officials").

75. See id. at 2037 ("Assuming the availability of a state forum with the authority and procedures adequate for the effective vindication of federal law, due process concerns would not be implicated by having state tribunals resolve federal-question cases.").

76. See id. at 2036-37.

77. Id. at 2037.

78. Id. at 2039.

79. See Fallon, supra note 64 , at 1143-44.

80. 209 U.S. 123, 176 (1908) (Harlan, J., dissenting). The federal court action in Ex Parte Young stopped an ongoing state court action by the Minnesota Attomey General. Although Justice Kennedy's remarks are reminiscent of Justice Harlan's, the situations were different in this important respect.

81. Idaho v. Coeur d'Alene, 117 S. Ct. 2028, 2039-40 (1997). 
test in Coeur d'Alene, Justice Kennedy disallowed federal jurisdiction over the Tribe's claim because of the "special sovereignty interests" implicated ${ }^{82}$ and the availability of a state forum.

Justices O'Connor, Scalia, and Thomas. Justices O'Connor, Scalia, and Thomas joined part of Justice Kennedy's opinion, including Justice Kennedy's thematic statements that "Eleventh Amendment immunity represents a real limitation on a federal court's federal-question jurisdiction;" the "real interests served by the Eleventh Amendment are not to be sacrificed to elementary mechanics of captions and pleading;" and the "[a]pplication of the Young exception must reflect a proper understanding of its role in our federal system and respect for state courts instead of a reflexive reliance on an obvious fiction." ${ }^{83}$ More to the point, Justices O'Connor, Scalia, and Thomas agreed with Justice Kennedy and Chief Justice Rehnquist that the Tribe's suit was the "functional equivalent" of a suit to quiet title against the State, ${ }^{84}$ and that the snit was nnique in that the Tribe sought to "eliminate altogether the State's regulatory power over the submerged lands at issue." ${ }^{285}$

Justice O'Connor was sharply critical of Justice Kennedy, however, for proposing changes in Ex Parte Young that would require a balancing test or an abandonment of the prospective/retrospective analysis. She argued that Justice Kennedy "unnecessarily recharacterize[d]" and "narrow[ed]" Ex Parte Young. ${ }^{86}$ Justice O'Connor found that "early Young cases fail to rely on the absence of a state forum as a basis for jurisdiction," and that Justice Kennedy "unnecessarily questions" the doctrine that "[w]hen a plaintiff seeks prospective relief to end an ongoing violation of federal rights, ordinarily the Eleventh Amendment poses no bar." 87 As for a case-by-case analysis of Ex Parte Young, Justice O'Connor found that "[o]ur case law simply does not support the proposition that federal courts must evaluate the importance of the federal right at stake before permitting an officer's suit to proceed," and furthermore, that "we have never doubted the importance of state interests in cases falling squarely within our past interpretations of the

82. See id. at 2040-43 ("[1]f the Tribe were to prevail, Idaho's sovereign interest in its lands and waters would be affected in a degree fully as intrusive as almost any conceivable retroactive levy upon funds in its Treasury.").

83. Id. at 2034.

84. See id. at 2040 (opinion of Kennedy, J.) ("[T]he declaratory and injunctive relief the Tribe seeks is close to the functional equivalent of quiet title action in that substantially all benefits of ownership and control would shift from the State to the Tribe."); see id. at 2043 (opinion of $O^{\prime}$ Connor, J.) (" $[A]$ s the Tribe concedes, the suit is the functional equivalent of an action to quiet its title to the bed of Lake Coeur d'Alene.").

85. Id. at 2043-44 (opinion of O'Connor, J.).

86. See id. at 2045 (citations omitted).

87. Id.

88. Id. at 2047. 
Young doctrine." ${ }^{89}$ The general theme of Justice O'Connor's opinion was that Justice Kennedy had replaced a "straightforward inquiry" with a "vague balancing test that purports to account for a 'broad" range of unspecified factors." $"$

Justices Souter, Stevens, Ginsburg, and Breyer. In dissent, Justice Souter, like the Ninth Circuit panel, thought the Tribe could proceed under Ex Parte Young. ${ }^{91}$ Although he disagreed with their ultimate judgment, he expressed "great satisfaction" that Justices O'Connor, Scalia, and Thomas did not join Justice Kennedy's reformulation of $E x$ Parte Young. ${ }^{92} \mathrm{He}$ did, however, find that "the effect of the two opinions [Justice Kennedy's and Justice O'Connor's] is to redefine and reduce the substance of federal subject-matter jurisdiction to vindicate federal rights. ${ }^{93}$ In particular, Justice Souter believed the majority gave short shrift to prior cases that involved suits against officers alleging illegal possession of property. ${ }^{94}$ Three cases figured prominently in this regard: United States v. Lee, ${ }^{95}$ Tindal v. Wesley, ${ }^{96}$ and Florida Department of State v. Treasure Salvors, Inc. ${ }^{97}$ The Ninth Circuit had relied on these cases in allowing the Tribe's Ex Parte Young action to proceed, and the facts and holdings of these cases are worth elaboration.

The property at issue in United States $v$. Lee was the Arlington estate of General Robert E. Lee's wife. ${ }^{98}$ The United States had bought the property for alleged default in taxes and had designated it as the Arlington National Cemetery. An offer had been made to pay the taxes prior to the sale, but the tax commissioners had a rule that overdue taxes must be paid by the owner in person. This rule was later nullified, thus invalidating the sale of the property. The owners brought an action for ejectment against two officers of the United States. A jury found for the owners, and the Supreme Court affirmed. Lee was a federal sovereign immunity case, but just as it continues to do, the Court "referred interchangeably to decisions in suits against federal officials and suits against state officials brought in federal court. ${ }^{.99}$ The Court did not claim to settle any rights against the United States but only against the officers. Although the Court determined that the federal officers were in

89. Id.

90. Id.

91. See id. at 2052-53 (Souter, J., dissenting).

92. See id. at 2048.

93. Id.

94. See id. at 2052-54.

95. 106 U.S. 196 (1882).

96. 167 U.S. 204 (1897).

97. 458 U.S. 670 (1982).

98. This summary of the facts is taken from Jaffe, supra note 14, at 23.

99. Richard H. Fallon, Jr. et al., The Federal Courts and the Federal System 1016 (HART \& WEChSLER eds., 4th ed. 1996). 
unlawful possession of the land, the United States could still subsequently bring an action to quiet its title. ${ }^{100}$

In Tindal $v$. Wesley, ${ }^{101}$ a New York plaintiff had purchased two parcels of land in Columbia, South Carolina, one of which contained a building known as Agricultural Hall. On February 20, 1892, the defendants, one of whom was the Secretary of State of South Carolina, "wrongfully entered into said premises and ousted the plaintiff." 102 The defendants continued to hold and possess the premises from that point forward. A jury found for the plaintiff in his suit against the state officers and awarded him possession of the land. The Supreme Court affirmed and reiterated the rationale of Lee that "[n]ot having submitted its rights to the determination of the conrt in this case, it will be open to the State to bring any action that may be appropriate to establish and protect whatever claim it has to the premises in dispute."103

In Treasure Salvors, a full century after Lee, treasure hunters claimed that Florida officials were wrongfully withholding artifacts recovered from a sunken Spanish galleon. ${ }^{104}$ The treasure hunters had made a contract with the State of Florida whereby the treasure hunters would receive seventy-five percent of the appraised value of recovered artifacts. ${ }^{105}$ However, the contract seemed to be premised on the belief that the "abandoned material [was] the property of the State of Florida." 106 In an unrelated suit subsequent to the contract with the treasure hunters, Florida and the United States were "engaged in litigation to determine the seaward boundary of submerged lands in the Atlantic Ocean and the Gulf of Mexico."107 What Florida had assumed to be within its borders for purposes of making the contract with the treasure hunters was found to be federal property in the suit against the United States. This border determination led the treasure hunters to demand im a federal court action that Florida officials return all artifacts that had been salvaged as property of the treasure hunters. The district court "rejected on multiple grounds the State's contractual claim to the property"108 and also rejected claims of Eleventh Amendment immunity. The Supreme Court, with a four-Justice plurality and Justice Brennan writing only for himself, affirmed the order transferring possession of the artifacts to the treasure hunters. Justice Stevens wrote for the

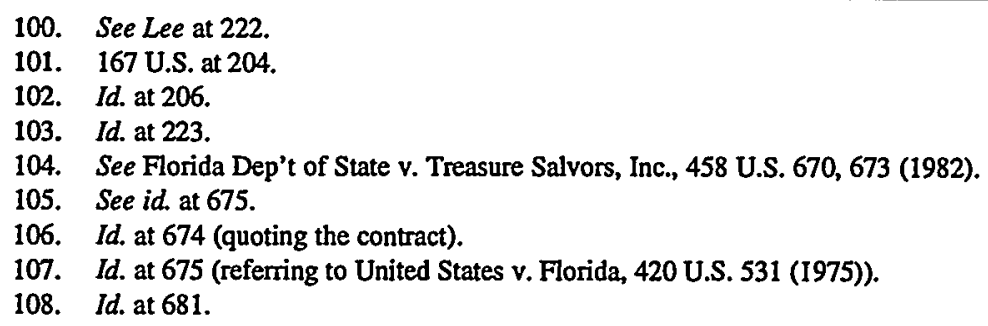


plurality and relied on Lee and Tindal in arguing that since the state officials did not have a "colorable claim to possession of the artifacts," the plaintiffs should be awarded possession. The Eleventh Amendment, however, precluded a final adjudication of the State's right to the artifacts. ${ }^{109}$

Justice Souter argued that the Tribe could proceed in federal court under Lee, Tindal, and Treasure Salvors. From these cases, Justice Souter maintained that the "Court has consistently held that a public officer's assertion of property title in the name of a government immune to suit cannot defeat federal jurisdiction over an individual's suit to be rid of interference with the property rights he claims."110 The Ninth Circuit had reached the same conclusion, but noted that other Circuits had questioned the viability of Lee, Tindal, and Treasure Salvors after Pennhurst's ruling that state law claims could not be pursued as part of an Ex Parte Young action in federal court. ${ }^{111}$ Justice Kennedy and Justice O'Connor both distinguished Treasure Salvors as a case involving state officers acting beyond their state-as opposed to federal-authority. ${ }^{12}$ As for Tindal and Lee, only Justice O'Connor tested their applicability, finding them to be cases where the Court might "distinguish between possession of the property and title to the property." 113 Justice O'Connor conclnded, however, that "[w]hatever distinction can be drawn between possession and ownership of real property in other contexts, it is not possible to make such a distinction for submerged lands."114

\section{B. Prospective versus Retrospective Relief in Coeur d'Alene}

Justice O'Connor criticized Justice Kennedy's opinion for replacing a "straightforward inquiry" into whether relief is prospective with

109. See id. at 697.

110. Idaho v. Coeur d'Alene, 117 S. Ct. 2028, 2051 (1997) (Souter, J., dissenting).

1I1. See Coeur d'Alene, 42 F.3d at 1253. The Ninth Circuit discussed two cases from other circuits that directly questioned the viability of Lee, Tindal, and Treasure Salvors. See id. at I253-55 (disagreeing with John G. and Marie Stella Kennedy Mem'l Found. v. Mauro, 21 F.3d 667 (5th Cir. 1994), and Fitzgerald v. Unidentified Wrecked and Abandoned Vessel, 866 F.2d 16 (1st Cir. 1989)). The Supreme Court made no comment on the apparent circuit split regarding Lee, Tindal, and Treasure Salvors, presumably because both Justice Kennedy and Justice O'Connor distinguished Lee, Tindal, and Treasure Salvors from the situation in Coeur d'Alene.

I12. See 117 S. Ct. at 2040 (opinion of Kennedy, J.); id. at 2044 (opinion of O'Connor, J.).

113. Id. at 2044 (opinion of $O^{\prime}$ Connor, J.) (emphasis added).

I14. Id. Justice O'Connor blurred together distinctions between the type of land at issue (submerged versus non-submerged land) and the Tribe's claim of sovereign authority over the Lake. As I discuss later on, the critical issue was that Idaho stood to lose sovereign authority over the Lake, as opposed to mere possession or ownership. That this was the key issue is not a function of the type of land (submerged or otherwise) but rather the type of plaintiff (an Indian tribe instead of a state citizen). See also infra note 132. 
"a vague balancing test." Jis Justice Kennedy, although guilty of this charge, did find that "if the Tribe were to prevail, Idaho's sovereign interest in its lands and waters would be affected in a degree fully as intrusive as almost any conceivable retroactive levy upon funds in its Treasury."16 Justice Kennedy seemed to consider the retrospective/prospective test, although he would supplement it with a weighing of state and federal interests in choosing a forum. ${ }^{177}$ Justice Souter noted Justice Kennedy's characterization of the relief as "retroactive" and "intrusive," and argued that Justice Kennedy improperly equated "intrusiveness" with "retrospectivity." As Justice Souter pointed out, the "exercise of Young jurisdiction for vindicating individual federal rights is necessarily 'intrusive,' simply because state officials sued under Young are almost always doing exactly what their States' legislative and administrative authorities intend them to do."118 Justice Souter concluded that "[i]f intrusiveness were to be a limitation on Young, the limitation would be terminal."119 Justice Souter and the other dissenters concluded that the Tribe had requested permissible prospective relief.

Justice $O^{\prime}$ Connor, on the other hand, trumpeted the "straightforward inquiry" of Edelman but never applied it to the case. Her rationale seemed to start with the question of whether the State was the real party in interest, not whether the relief being sought was prospective or retrospective. She stated that "[w] here a plaintiff seeks to divest the State of all regulatory power over submerged lands-in effect, to invoke a federal court's jurisdiction to quiet title to sovereigu lands-it simply cannot be said that the suit is not a suit against the State." 220 Why not? Is it because the relief would be "retrospective"? Is it because the Tribe did not claim an ongoing violation of federal law? Justice O'Connor accused Justice Kennedy of changing the rules of the Ex Parte Young inquiry, but then she never applied the straightforward retrospective/prospective inquiry herself. The gist of her opinion may be that Coeur d'Alene is sui generis, and in all other cases, the retrospective/prospective analysis will apply.

115. Id. (opinion of O'Connor, J.).

116. Id. at 2043 (opinion of Kennedy, J.) (emphasis added). This portion of Justice Kennedy's opinion was joined by Justices O'Connor, Scalia, and Thomas.

117. Coeur d'Alene has been described as a case where "a majority held that in the particular circumstances, a claim concededly limited to prospective relief was nonetheless barred by the Eleventh Amendment." Richard H. FalloN, JR. ET AL., supra note 99, at 39 (Supp. 1997). This is a tricky conclusion to draw because Justice Kennedy did seem to conpare the relief to being "retroactive," although at other times he said that the Tribe sought "prospective injunctive relief," $117 \mathrm{~S} . \mathrm{Ct}$. at 2040, seeming to concede that the relief was "prospective."

118. Idaho v. Coeur d'Alene, 117 S. Ct. 2028, 2055 (1997) (Souter, J., dissenting).

119. Id.

120. Id. at 2047 (opinion of $O^{\prime}$ Connor, J.). 


\section{Beyond Retrospective/Prospective: Balancing Interests}

It is clear from Coeur d'Alene that retrospective/prospective analysis is still the relevant Ex Parte Young test, but it is unclear if any supplemental tests were or will be created. In arguing for a balancing of federal and state interests, Justice Kennedy pointed to Milliken (II) ${ }^{121}$ as an instance where a viable Eleventh Amendment defense to federal court jurisdiction was defeated because of the federal interests involved. ${ }^{122}$ Justice Kennedy concluded that "the substantive provisions of the Fourteenth Amendment themselves offer a powerful reason to provide a federal forum." 123 Justice O'Connor, Justice Souter, and the Justices that joined those respective opinions (and thus a majority of the Court) objected to Justice Kennedy's characterization of Milliken (II) and claimed that Milliken (II) was solely an inquiry into whether the relief being sought was retrospective or prospective. ${ }^{124}$ Justice O'Connor and Justice Souter could easily refer to the incantation in Milliken (II) that the ordered relief would "operate prospectively."125

In support for his argument that Ex Parte Young should "reflect the real interests of States," 126 Justice Kennedy drew support from "Seminole Tribe's implicit analogy of Young to Bivens [v. Six Unknown Fed. Narcotics Agents]."127 In Seminole Tribe, the Court had denied an Ex Parte Young action because Congress had provided a detailed remedial scheme. ${ }^{128}$ The "detailed remedial scheme" rationale did not come from prior Ex Parte Young cases, but from Bivens and its progeny. Those cases, particularly Schweiker v. Chilicky, ${ }^{129}$ involved implied rights of action under federal law. In Coeur d'Alene, Justice Kennedy decided that Ex Parte Young could also be limited by "special factors counseling hesitation," "130 yet another concept from the Bivens family. After stating that the "range of concerns to be considered" should be "broad," Justice Kennedy concluded that Ex Parte Young should "reflect the real interests of States." Just as they rejected Justice Kennedy's characterization of Milliken (II), neither Justice O'Connor

121. 433 U.S. 267 (1977). Milliken (II) was discussed earlier, see supra notes 63-65 and accompanying text.

122. See $117 \mathrm{~S}$. Ct. at 2039.

123. Id.

124. See id. at $2051 \mathrm{n.6}$ (Souter, J., dissenting) ("The sole enquiry [in Milliken (II)] was whether the relief sought was fairly characterized as prospective."); see id. at 2047 (opinion of $0^{\prime}$ Connor, J.) ("Our case law simply does not support the proposition that federal courts must evaluate the importance of the federal right at stake before permitting an officer's suit to proceed.").

125. See 433 U.S. at 290.

126. $117 \mathrm{~S}$. Ct. at 2039-40.

127. Id. at 2039. See Bivens v. Six Unknown Fed. Narcotics Agents, 403 U.S. 388 (1971).

128. See Seminole Tribe of Florida v. Florida, 116 S. Ct. 1114, 1132-33 (1996).

129. 487 U.S. 412 (1988).

130. 117 S. Ct. at 2039 (quoting Bivens, 403 U.S. at 396). 
nor Justice Souter accepted adding "special factors counseling hesitation" to Ex Parte Young doctrine.

\section{Beyond Retrospective/Prospective: Functional Equivalents}

Justice Kennedy's "balancing" approach to Ex Parte Young was not accepted by the Court, but a new doctrine of "functional equivalents" was accepted. Numerous aspects of Coeur d'Alene might compel a reading that the case is sui generis and that any doctrine of "functional equivalents" will go no further than land disputes between States and Tribes. For example, both Justice Kennedy and Justice O'Connor emphasized that the submerged lands at issue would be beyond the regulatory jurisdiction of the State should the Tribe prevail. ${ }^{131}$ This aspect of the case would not arise with a non-sovereign as plaintiff. ${ }^{132}$ Should the Court breathe life into a doctrine of "functional equivalents," however, it could easily eviscerate Ex Parte Young for one simple reason: the Ex Parte Young doctrine is, has been, and always will be a fiction, because every Ex Parte Young action is the functional equivalent of a suit against the State. As Professor Davis described it, Ex Parte Young is about "suing the government by falsely pretending to sue an officer." "133 As Justice Souter noted in dissent, every successful Ex Parte Young action functionally bars a State from doing something. ${ }^{134}$ After all, a State can only act through its officers.

\section{E. The Doctrine of Ex Parte Young and Edelman after Coeur d'Alene}

What happened to Ex Parte Young and Edelman in Coeur d'Alene? Perhaps the "functional equivalent" concept could lead to major changes in the doctrine, but Coeur d'Alene hardly foreshadows major developments. For now, the straightforward retrospective/prospective inquiry prevails except in cases like Coeur d'Alene. To understand such cases, and why the prevailing doctrine has and will continue to break down, we must speculate as to how the Justices conceptualized the

131. See id. at 2040 (opinion of Kennedy, J.) ("The suit seeks, in effect, a determination that the lands in question are not even within the regulatory jurisdiction of the State."); see id. at 2044 (opinion of O'Connor, J.) ("Here, the Tribe seeks a declaration not only that the State does not own the bed of Lake Coeur d'Alene, but also that the lands are not within the State's sovereign jurisdiction.").

132. If the Tribe were to prevail, the Lake would be part of the Coeur d'Alene Indian reservation, which would not even be part of Idaho's sovereign territory. In effect, it would redraw the map of Idaho so as to not include Lake Coeur d'Alene. If an individual were the plaintiff, Idaho might lose "possession" of the Lake, but it would still very much be part of Idaho's sovereign jurisdiction, and Idaho could regulate it just like it regulates all other privately held land. The key distinction in Coeur d'Alene, which the opinions confuse at times, was not the type of land at issue, but the type of plaintiff.

133. See Davis, supra note 53.

134. See 117 S. C. at 2053 (Souter, J., dissenting). 
problems in Coeur d'Alene. We need not blindly guess about such things; instead, we can test out Professor Jaffe's approach toward explanation.

\section{IV}

\section{Existential Categories in Coeur d'Alene}

\section{A. Professor Jaffe's Suits against Governments and} Officers: Sovereign Immunity

In light of the authority-stripping theory, the retrospective/prospective limit, and abstract presuppositions of our federalism, the permissibility of officer suits would seem reducible to a simple rule: individuals may seek prospective relief against state officers in federal court to stop an ongoing violation of federal law and compel compliance with federal law. ${ }^{135}$ Although this rule does reflect the incantations we have come to expect from the Court, it provides very little guidance in hard cases like Coeur d'Alene because (1) it cannot capture all of the competing interests in widely varying contexts, and (2) it very indirectly builds upon the conceptual frameworks that appear to guide the Court in sovereign immunity cases. ${ }^{136}$ In 1963 Professor Jaffe offered what is routinely called a "classic" piece of scholarship regarding sovereign immunity. ${ }^{137} \mathrm{He}$ advised that rather than asking the "abstract analytic" questions to find out whether immunity should apply, we must look instead to our "legal tradition." 138

Professor Jaffe's survey of American sovereign immunity and officer suits was written prior to Edelman, and its scope preceded Ex Parte Young. If we had any doubts regarding the relevance of 19th century cases to current sovereign immunity doctrine, we need look no further than Seminole Tribe, which reaffirmed and reinvigorated the 1882 case

135. See supra Part II.

136. Such a critique of the retrospective/prospective doctrinal rule is frequently leveled at "rulebased decisionmaking" in general. See Kathleen M. Sullivan, Foreword: The Justices of Rules and Standards, 106 HARv. L. REv. 22, 66-67 (1992) (referring to criticism that "[r]ule-based dccisionmaking suppresses relevant similarities and differences" between cases, and that "standards make visible and accountable the inevitable weighing process that rules obscure").

137. See generally Jaffe, supra note 14. See, e.g., Susan Bandes, Reinventing Bivens: The SelfExecuting Constitution, 68 S. CAL. L. REv. 289, 335 (1995) (referring to Jaffe's article as a "classic"). Professor Jaffe's article has been cited in 10 Supreme Court cases involving sovereign immunity, including Coeur d'Alene. The other cases are Seminole Tribe, Int'l Primate Protection League v. Tulane Educ. Fund, 500 U.S. 72 (1991), Atascadero State Hosp. v. Scanlon, 473 U.S. 234 (1985), Pennhurst, Nevada v. Hall, 440 U.S. 410 (1979), Scheuer v. Rhodes, 416 U.S. 2332 (1974), Employees of the Dep't of Pub. Health \& Welfare of Missouri v. Dep't of Pub. Health \& Welfare of Missouri, 411 U.S. 279 (1973), Parden v. Terminal Ry. of the Alabama State Docks Dep't, 377 U.S. 184 (1964), and Rabinowitz v. Kennedy, 376 U.S. 605 (1964).

138. See Jaffe, supra note 14, at 28-29. Regarding the English tradition, Professor Jaffe found that "expediency" was a far better determinant of whether an officer could be sued than any "abstract theory as to whether the action was really against the state." Id. at 3 . 
of Hans v. Louisiana. From the legal tradition that included Hans, Professor Jaffe concluded that sovereign immunity for officers is at its zenith when a suit requires "enforcement of contracts, treasury liability for tort, [or] the adjudication of interests in property which has come unsullied by tort into the bosom of the government." ${ }^{139}$ In these areas, Professor Jaffe found that exceptions to sovereign immunity were rare. However, sovereign immunity is at its nadir when "state policy threatens federal instrumentalities or federal programs or is in defiance of constitutional inhibitions (other than obligation of contract)." 40 In addition, Professor Jaffe found that the Court opposed intruding too deeply on the "general powers and functions of [state] government."141

Two early officer suits found sovereign immunity at its nadir because important federal interests were directly threatened and officers held property by means of trespass. ${ }^{142}$ In Osborn $v$. United States Bank, ${ }^{143}$ Ohio had levied a tax on the Bank of the United States with the intention of destroying it, a motive not lost on Chief Justice Marshall, who found the Ohio officers amenable to suit and forced them to return the tax money. ${ }^{144}$ Osborn came to stand for the principle that "where the plaintiff complained that a state officer had inflicted a trespass contrary to the Constitution or the statutes of the United States, he could have [even monetary] relief."145 In United States $v$. Lee, ${ }^{146}$ which I discussed earlier, ${ }^{147}$ the Court followed Osborn in ordering the return of land that had been seized by federal officials for unpaid taxes. The tax default resulted from a payment rule later held invalid. Professor Jaffe found the majority most concerned with "the potential defiance of the Constitution should the United States be permitted to take property without just compensation."148 Justice Miller, who wrote the majority opinion in Lee, would later write another majority opinion, however, in which he characterized Lee as a case, like Osborn, involving "trespasses by an officer." 49 Later in his article, Professor Jaffe included Lee in a group of sovereign immunity cases involving property where the original possessor-either the individual plaintiff or the defendant

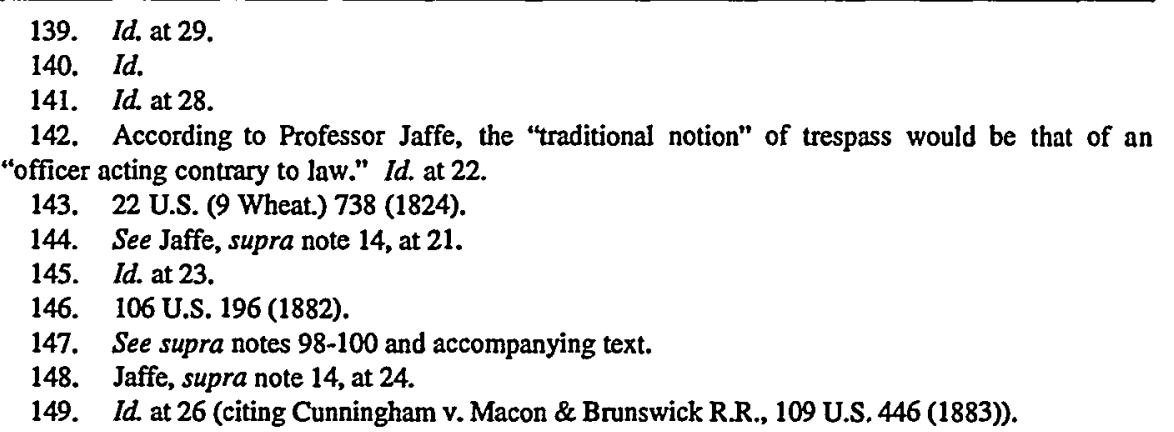


government-prevailed, perhaps showing a pattern based on who originally possessed the property. ${ }^{150}$

The early tradition regarding trespasses by officers and the protection of important federal interests gave way to refusals to intrude too deeply on the administration of state government in "a series of cases which are part of the long drawn-out battle between local interests and the national banking communities over the terms and conditions of financing the railroads and other large works."151 The Court allowed states, through the defense of sovereign immunity, to repudiate the monetary obligations of state bonds. ${ }^{152}$ In examining cases after Lee that upheld sovereign immunity for officers, Professor Jaffe stressed "how serious and controversial" it would have been for a federal court to present state legislative and executive authorities with a judgment to be paid. ${ }^{153}$ In formulating exceptions to sovereign immunity for officers in suits where the government might have a property interest, Justice Miller included only cases of trespass and cases "where the law has imposed ... a well defined duty in regard to a specific matter, not affecting the general powers or functions of the government."154 With this in mind, Professor Jaffe rationalized the result in Pennoyer v. McConnaughy, ${ }^{155}$ where the Court enjoined a state's sale of land due to the plaintiff's lawful land pateuts on it. Professor Jaffe noted that "the enforcement of [the program in Pennoyer] does not affect 'the general powers and functions of the government' as would the enforcement of a large bond issue."156 As for plaintiffs seeking redemption on state bonds, only one highly idiosyncratic case upheld a general monetary obligation of a state government. ${ }^{157}$

The legal traditions regarding sovereign immunity and officer suits Professor Jaffe identified may still affect how the Court decides

150. See id. at 31-33.

151. Id. at 25.

152. See, e.g., In re Ayers, 123 U.S. 443 (1887). However, at the same time states could repudiate state bonds, the Court forced cities and counties to honor municipal bonds. Indeed, the Court was vigilant to the point of

enforcing bonds which the State court had held invalid without overruling any [state] decision; construing State statutes-on the powers of municipal officers, on debt limits, on the privileges of railroad corporations, ctc.- - contrary to the construction given them by the State courts; and exercising unrestrainedly that independence in matters of "general jurisprudence' which a later Court abandoned as 'an unconstitutional assumption of powers by the Courts of the United States which no lapse of time or respectable array of opinion should make us hesitate to comect."

Charles Fairman, Reconstruction and Reunion, 1864-88, at 919 (The Oliver Wendell Holmes

Devise History of the Supreme Court of the United States, vol. 6, Paul A. Freund, ed., 1971).

153. See Jaffe, supra note 14 , at 25 .

154. Cunningham v. Macon \& Brunswick R.R., 109 U.S. 446, 452 (1883) (emphasis added).

155. 140 U.S. 1 (1891).

156. Jaffe, supra note 14, at 28.

157. See id. at 27 (citing McGahey v. Virginia, 135 U.S. 662 (1890)). 
sovereign immunity questions and how it will use the current analytic tools. Professor Jaffe identified patterns or categories of cases where sovereign immunity was either rare or the rule. Professor Scalia, in a somewhat similar sovereign immunity project, used the phrase "existential categories," in contrast with "analytical" or "theoretical" categories. ${ }^{158}$ In Professor Scalia's survey of suits against federal officials, he found that sovereign immunity was rare and even "utterly inconceivable" in suits falling in the existential categories of public-lands cases, post office cases, and tax cases. ${ }^{159}$ Within these existential categories, federal judges, who are "always within the context of a particular set of facts,"160 would feel "the pull of factually similar precedent," as opposed to the pull of a "broad conceptual category"162 or principle.

Testing Professor Jaffe's conclusions against sovereign immunity cases post-dating his article produces an effect similar to what Professor Scalia observed. Professor Jaffe identified various existential categories which are not nearly as "well-defined and fully developed" as the existential categories identified by Professor Scalia. ${ }^{163}$ Nevertheless, even Professor Jaffe's partially developed categories are quite helpful in understanding recent sovereign immunity cases.

For example, we might consider Milliken (II) a case similar in existential category to Osborn. A state was defying desegregation. Although explicitly claiming nothing more than the retrospective/prospective inquiry, the Milliken (II) Court may have viewed desegregation cases as a question of overwhelming federal interests, like Osborn. We should not be surprised that sovereign immunity was at its nadir. Professor Jaffe's legal traditions, or Professor Scalia's existential categories, provide a coherent perspective on Milliken (II), whereas prospective/retrospective analysis does not. Just as Professor Scalia found it "utterly inconceivable" that the Court might alter its invariable disregard of sovereign immunity in post office cases, so too was it probably equally inconceivable that federal court-ordered desegregation might be impeded by state sovereign immunity. ${ }^{164}$

Professor Jaffe's insights also provide a number of critical questions regarding how the Court might have conceptualized or categorized Coeur d'Alene, which is really the test concerning this Comment. Was Coeur d'Alene a case where an important federal program or federal interest was threatened? If the Court had categorized it as such, then we

158. See Scalia, supra note 1 , at $881-82$.

159. See id. at 913-15.

160. Id. at 919 (emphasis added).

161. Id.

162. Id.

163. See id. at 882.

164. See id. at 881-82. 
might expect a suit against state officers to proceed in federal court. Whom did the Court view as the original possessor of the property in Coeur d'Alene? Idaho? The Tribe? The United States? Did Idaho take possessiou of the property through a trespass or tort? Would a judgment against the state officers have affected the general powers or functions of the state government, much as forcing the State to honor a large bond issue would have? How controversial would it have been for a federal court to order Idaho to transfer to the Tribe all sovereign authority over "[o]ne of the Nation's most beautiful lakes"? ${ }^{165}$ None of these considerations, however, are explicitly part of the officer suit doctrine encapsulated in the rule that individuals may seek prospective relief against state officers in federal court to stop ongoing violations of federal law.

We can tell by the majority's treatment of the prevailing Ex Parte Young doctrine in Coeur d'Alene that the doctrine was conceptually bankrupt. Justice Kennedy made a feeble attempt to relate the requested relief to a retroactive award from the state treasury; Justice O'Connor and company joined that portion of Justice Kennedy's opinion, but Justice $\mathrm{O}^{\prime}$ Connor did no prospective/retrospective analysis herself. Essentially, the majority merely concluded that the suit could not proceed because it was too much like a suit directly against the State-an even more bankrupt concept. As the next section explores, the legal traditions or existential categories identified by Professor Jaffe do seem to give substance to how the Court conceptualized and categorized Coeur d'Alene.

\section{B. The Majority Did Not Sense That Important Federal Interests Were Being Threatened in Coeur d'Alene}

Professor Jaffe concluded that "[w] here the enforcement of state policy threatens federal instrumentalities or federal programs or is in defiance of constitutional inhibitions (other than obligation of contract), Osborn and Ex Parte Young are the prototypes."166 Neither Justice Kennedy nor Justice O'Connor conceptualized Coeur d'Alene as a case implicating important federal interests, so we should not be surprised that they were reluctant to uphold an Ex Parte Young action. ${ }^{167}$ As conclusive proof that at least Justice Kennedy did not bring such a perspective to the case, consider his reformulation of Ex Parte Young. While proposing to balance the federal interests in the case, at no point did

165. Idaho v. Coeur d'Alene, 117 S. Ct. 2028, 2031 (1997).

166. Jaffe, supra note 14, at 29.

167. It is again worth noting that the Court knew that the United States had already filed in federal court on the Tribe's behalf. See supra note 48 . The Court did not need to perceive itself as the sole defender of the Tribe's interests in a federal forum because the executive braneh had already asserted a federal interest on the Tribe's behalf. 
Justice Kennedy balance or even identify any federal interest in a federal forum for suits between Tribes and the States. Instead, Justice Kennedy was concerned solely with threats to Idaho's sovereignty. Justice O'Connor, likewise, made no mention of special federal interests in providing the Tribe with a federal forum. ${ }^{168}$

Although the majority did not categorize Coeur d'Alene in terms of federal interests, other Justices might have. Justice Souter showed signs of this perspective, noting that "when the plaintiff suing the state officers has been an Indian tribe, the readiness of the state courts to vindicate the federal right has been less than perfect." 169 Were he still on the bench, we might expect Justice Blackmun to conceptualize Coeur d'Alene in terms of threats to federal interests. In his dissent in Blatchford, where the majority held that the Eleventh Amendment applies to suits by Indian tribes, Justice Blackmun argued that Indian tribes deserved greater access to the federal judiciary because "the vindication of Native American rights has been the institutional responsibility of the Federal Government since the Republic's founding." 170 Justice Blackmun might have made the same arguments in Coeur d'Alene in support of federal court jurisdiction.

\section{The Majority Did View Coeur d'Alene as a Politically}

\section{Controversial Threat to the General Powers of the State Government}

Professor Jaffe found that the Court limited cases like Lee and Osborn because it sensed the potential for controversy should federal courts order state legislatures and executives to pay large judgments. Professor Jaffe also concluded that the Court upheld immunity if a suit-such as one involving a large state bond issue-might have substantial effects on the "general powers or functions of government." The majority in Coeur d'Alene was keenly aware of threats to general state powers and the politically controversial aspects of the Tribe's suit. Both Justice Kennedy and Justice O'Connor pointed out that the Tribe was not seeking mere possession or ownership over the Lake. The Tribe

168. Commentators have noted that the Supreme Court has come to disfavor Indian sovereignty when protecting its continued existence is at the expense of state or non-Indian interests. See L. Scott Gould, The Consent Paradigm: Tribal Sovereignty at the Millennium, 96 Colum. L. REv. 809, 810 (1996) ("[T]he Supreme Court has changed the course of two centuries of law. Tribes, whose sovereign powers were once coexteusive with their territory, now have authority over few but tribal members."); David Getches, Conquering the Cultural Frontier: The New Subjectivism of the Supreme Court in Indian Law, 84 CALIF. L. REv. 1573, I575 (1996) ("Over the last fifteen years, partly as a result of tribes' broader assertions of power over reservation activity, non-Indian interests have been allowed to play a greater role in Indian country jurisdiction disputes.").

169. 117 S. Ct. at 2056 n.11 (Souter, J., dissenting).

170. Blatchford v. Native Village of Noatak, 501 U.S. 775, 794 (1991) (Blackmun, J., dissenting).

17I. Jaffe, supra note 14 , at 28. 
was seeking sovereignty over the Lake, which would "eliminate altogether the State's regulatory power over the submerged lands at issue." 172 Losing all regulatory power over land a state considers within its borders directly affects the general powers or functions of government.

In addition, a relatively obscure aspect of Coeur d'Alene only brought to light in Justice Souter's dissent and the oral argument suggests that a federal court victory for the Tribe would have left Idaho with no legal recourse. Federal law might have prevented Idaho from suing the Tribe had the Tribe prevailed, ${ }^{173}$ and federal law would prohibit Idaho from exercising eminent domain or otherwise acquiring tribal lands directly from the Tribe. ${ }^{174}$ In addition, federal law may also preclude a subsequent quiet title action by Idaho without the consent of the United States. ${ }^{175}$ Although Lee, Tindal, and Treasure Salvors held that Ex Parte Young actions could proceed against state officers without binding the State itself, ${ }^{176}$ the complexities of federal Indian law made Coeur d'Alene a much different case and a much greater threat to state sovereignty. Justice Kennedy and Justice O'Connor did not mention this distinguishing characteristic of Coeur d'Alene, but it was present in the case. ${ }^{177}$ It is somewhat puzzling they did not mention Idaho's lack of

172. 117 S. Ct. at 2043-44 (opinion of O'Connor, J.).

173. See $117 \mathrm{~S}$. Ct. at $2052 \mathrm{nn} .7$ \& 8 (Souter, J., dissenting).

174. 25 U.S.C.A. $\$ 177$ (West 1997) provides:

No purchase, grant, lease, or other conveyance of lands, or of any title or claim thereto, from any Indian nation or tribe of Indians, shall be of any validity in law or equity, unless the same be made by treaty or convention entered into pursuant to the Constitution. Every person who, not being enuployed under the authority of the United States, attempts to negotiate such treaty or convention, directly or indirectly, or to treat with any such nation or tribe of Indians for the title or purchase of any lands by them held or claimed, is liable to a Id. penalty of $\$ 1,000$

175. The Quiet Title Act, 28 U.S.C.A. \& 2409a (West 1997), provides in part:

The United States may be named as a party defendant in a civil action under this section to adjudicate a disputed title to real property in which the United States claims an interest, other than a security interest or water rights. This section does not apply to trust or restricted Indian lands....

Id. (emphasis added).

176. See supra notes $118-30$ and accompanying text. .

177. The potential alternatives for ldaho should the Tribe prevail in its Ex Parte Young action were the subject of the initial exchange between the Court and the assistant attorney general for Idaho as the petitioner at oral argument:

MR. STRONG: Under the injunctive and declaratory relief sought by the Tribe, the Tribe would be awarded quiet title and exclusive possession of these lands.

Question: But it would not, as 1 understand it, be a decree that would estop the State if the State later wanted to contest the title.... .1sn't that correct? [short exchange omitted]

MR. STRONG: Your Honor, the very nature of this [sic] lands is what brings the difficult interplay with Ex parte Young. Under the officer's suit rationale it is assumed that the State simply could bring another action to clear its title to these lands, but if the Tribe were awarded possession of these lands, under section $282409 \mathrm{a}$, the Federal Quiet Title Act specifically precludes an action by the State against the United States Government for possessions [sic] of lands held in trust for the benefit of the Tribe. Likewise, tribal sovereign immunity would preclude the State from bringing an action against the tribal—against the- 
recourse should the Tribe prevail in federal court, because it would seem to cut in their favor as a way to distinguish Lee, Tindal, and Treasure Salvors.

The majority clearly had a sense for the politically controversial aspects of the case, or at least the significance of the disputed property. As Justice Kennedy described it at the start of his opinion, "In the northern region of Idaho, close by the Coeur d'Alene Mountains which are part of Bitterroot Range, lies tranquil Lake Coeur d'Alene. One of the Nation's most beautiful lakes, it is some 24 miles long and 1 to 3 miles wide." 178 We might add to this depiction the booming resort business that many travel writers have noted: "Coeur d'Alene is now a worldwide destination. The towering, lavish Coeur d'Alene Resort draws thousands annually by its Mobil four-star accommodations and to play its posh golf course with a one-of-a-kind floating green [on Lake Coeur d'Alene]."179 Given the property at issue, we might try to distinguish Coeur d'Alene from Lee, Tindal, and Treasure Salvors purely by the significance of the disputed property. In the case of Lee, however, it is difficult to say that Arlington National Cemetery is somehow trivial in comparison to Lake Coeur d'Alene. More importantly, it seems doubtful Coeur d'Alene would have come out differently had the disputed property been one of the nation's uglier, less touristed lakes (provide your own example), although the gravity of the potential sovereign authority loss might not have seemed so severe. There is a difference in degree with regard to the siguificance of the property in Coeur d'Alene in comparison with Tindal, Treasure Salvors, and arguably Lee, but the real distinction is the potential loss of sovereigu authority to regulate, purchase, or acquire through inverse condemnation the property in Coeur d'Alene.

The intrusiveness and political sensitivity of adjudicating the Tribe's claim has parallels with the state bond cases. As Professor Jaffe remarked about the Court's decision against sovereign immunity in Pennoyer v. McConnaughy, "the enforcement of this program does not

QUESTION: So you're saying it's the Quiet Title Act that would in effect require the preclusion?

MR. STRONG: The Quiet Title Act would because of the language in the act that precludes an action by a State against the United States for lands that are held in trust for the benefit of the Tribe.

Transcript, U.S. S. Ct., 1996 WL 604993, at 4-5.

Shortly following this exchange, the attomey general was asked about the possibility of the State calling out the National Guard to take possession of the land to force the adjudication of its claim to title.

178. 117 S. Ct. at 2031 (opinion of Kennedy, J.).

179. Ric Clarke, Gem State's Jewel; Coeur d'Alene Resort, a Millionaire's Gamble, Revives Northern Idaho, ARIz. REpublic, Aug. 10, 1997, at Tl; see also Candyce H. Stapen, Mining the Attractions of Coeur d'Alene Area, WASH. TIMES, Mar. 2, 1997, at E2 (noting lake cruises and jet ski, kayak, and paddleboat rentals at Lake Coeur d'Alene). 
affect 'the general powers and functions of the government' as would the enforcement of a large bond issue." 180 Although involving property claims, Lee, Tindal, and Treasure Salvors were similar to Pennoyer in having a limited impact on the powers and function of state government. But just as one of the essential functions of state government is to raise revenue and determine its allocation, so too is it an essential function of state government to regulate and manage all of the public and private property within state boundaries. If a federal court forces a state to pay a money judgment, the state loses its sovereign authority over its revenue and allocations. Similarly, if Idaho is forced to relinquish sovereign authority over Lake Coeur d'Alene, the state loses more than mere possession; the Lake is no longer part of the State of Idaho and beyond the State's regulatory power. If the disputed property is more than some trivial parcel, the loss of sovereign authority will command attention, as it did in Coeur d'Alene. But even if the Tribe's action had involved some trivial parcel of property, Idaho would still face relinquishing sovereign authority over property, which was not at issue in Lee, Tindal, or Treasure Salvors.

Only in rare exceptions have states been forced to honor monetary obligations in an officer suit. In the portion of his opinion joined by Justices O'Connor, Scahia, and Thomas, Justice Kennedy observed that "if the Tribe were to prevail, Idaho's sovereign interest in its lands and waters would be affected in a degree fully as intrusive as almost any conceivable retroactive levy upon funds in its Treasury." 181 The Coeur d'Alene majority evidently felt the factual pull of state bond cases from the 1800 s much more than a pull from the property disputes in Lee, Tindal, and Treasure Salvors. Losing sovereign authority over property seemed akin to losing sovereign authority over how to allocate state revenues.

Justice Souter's dissent dismissed the uniqueness of the Lake and the Tribe's suit. He posed the following hypothetical: "A State obliged to choose between power to regulate a lake and lake bed on an Indian reservation and power to regulate economic affairs and punish offenders [as in Ex Parte Young] would not (knowing nothing more) choose the lake."182 Of course, Justice Souter's hypothetical depends on the lake at issue, but Justice Souter, unlike the majority, paid no special regard to the lake at issue in Coeur d'Alene. Likewise, he paid no special regard to the plaintiff at issue, dismissing all of the complications the State might face because of federal Indian law should the Tribe prevail

180. Jaffe, supra note 14 , at 28 .

181. $117 \mathrm{~S}$. Ct. at 2043.

182. Id. at 2054 (Souter, J., dissenting). 
on an Ex Parte Young action, ${ }^{183}$ including the possibility that Idaho may have had no legal recourse. ${ }^{184}$ As for the loss of sovereign authority over Lake Coeur d'Alene distinguishing Lee, Tindal, and Treasure Salvors, Justice Souter correctly noted that if the Lake rightfully belongs to the Tribe, then it is no longer part of the State of Idaho, and Idaho "ha[s] no legitimate sovereign interest in regnlating submerged lands located outside state borders."185 As an analytic matter, this may be true; as a practical matter regarding Lake Coeur d'Alene, it is surely false.

\section{The Majority Did Not Conceive of Idaho as Having Wrongfully Acquired the Lake}

Professor Jaffe concluded that the Court will not adjudicate "interests in property which has come unsullied by tort into the bosom of government"186 and that "[f]or the most part the Court will not entertain actions to compel the transfer of land which has come lawfully into the possession of the state."187 The majority in Coeur d'Alene, rightly or wrongly, did not conceive of Idaho as holding the Lake through any wrongdoing. This bolstered the officials' claims of immunity.

Throughout Justice Kennedy's opinion there seeins to be little doubt regarding Idaho's lawful possession of the Lake, even though ownership of the Lake was the ultinate issue the Tribe disputed. In stressing Idaho's sovereign interests, Justice Kennedy noted that "lands underlying navigable waters have historically been considered 'sovereign lands.' State ownership of them has been 'considered an essential attribute of sovereignty."'188 Justice Kennedy even lapsed into referring to the disputed lands as if they belonged to Idaho when he concluded as part of the majority that "if the Tribe were to prevail, Idaho's sovereign interest in its lands and waters would be affected in a degree fully as intrusive as any conceivable retroactive levy upon funds m its Treasury." 189 Justice Souter picked up on Justice Kennedy's conceptualization of the Lake as lawfully belonging to Idaho, pointing out as I previously noted that "Idaho indisputably has a significant sovereign interest in regulating its submerged lands, but it has no legitimate sovereign interest $\mathrm{m}$ regulating submerged lands located outside state borders." 190 Although the core of the conflict between the Tribe and the

183. See id. at $2052 \mathrm{nn} .7$ \& 8 (Souter, J., dissenting).

184. See supra notes $173-177$ and accompanying text.

185. 117 S. Ct. at 2054 (Souter, J., dissenting).

186. Jaffe, supra note 14, at 29.

187. Id. at 24.

188. 117 S. Ct. at 2041.

189. Id. at 2043 (emphasis added).

190. Id. at 2054 (Souter, J., dissenting) (citations omitted). 
State was ownership of the Lake, the majority conceived of the Lake as lawfully in the possession of Idaho.

We can contrast the majority's conception of Idaho's possession of the Lake with the government possession at issue in Lee, Tindal, and Treasure Salvors. In Lee, the government acquired the land through a tax default that only occurred because of an invalid tax rule. In Tindal, the state officers arrived at the premises and "ousted" the plaintiff. In Treasure Salvors, the State took possession through a subsequently invalid contract that was "entered into as a result of the "coercive acts of the Division of Archives in threatening arrest and confiscation." "191 In Coeur d'Alene, Idaho was never accused of having taken possession of the Lake through an act that might be characterized as wrongful. Indeed, although the suit in Coeur d'Alene is only the most recent action in a "long-standing dispute between the Tribe and the State of Idaho," officers of the federal government always dealt with the Tribe and continually negotiated and re-drew the boundaries of the Coeur d'Alene Reservation. ${ }^{192}$ The majority conceived of the Lake as arriving "unsullied by tort into the bosom of the government," 193 to use Professor Jaffe's phrase, and in such situations sovereign immunity is at its zenith.

Yet again, other Justices might have conceptualized Idaho's current possession of the Lake quite differently. There are doubtless examples of how Idaho settlers and officials tested the borders of the Coeur d'Alene Reservation and prompted the federal government to negotiate a sale of tribal land to avert future disputes. For example, "[t]he discovery of valuable minerals in the Lake Coeur d'Alene region created additional demands for non-Indian use of the lands and waters within the Coeur d'Alene Reservation." 194 To diminish Idaho's sovereign immunity conceptually, Idaho must be conceived of as acquiring the Lake by wrongdoing.

\section{E. Summary: Applying the Legal Traditions to Coeur d'Alene.}

Professor Jaffe's insights from his survey of sovereign immunity cases resonate in the Court's conceptualization of Coeur d'Alene. The majority did not conceive a threat to federal interests or any wrongdoing on the part of Idaho. The majority did find, however, a deeply intrusive and politically sensitive dispute between an Indian tribe and a

191. Florida Dep't of State v. Treasure Salvors, Inc., 458 U.S. 670, 674 n.4 (I982) (opinion of Stevens, J.).

192. See Brief for the United States as Amicus Curiae Supporting Respondents, 1996 WL 376983, at 2-10 (chronicling dealings between the United States, Idaho, and the Tribe regarding Lake Coeur d'Alene).

193. Jaffe, supra note 14, at 29.

194. Brief for the United States, supra note 192, at 6. 
western state over one of the nation's most beautiful lakes. At stake in this dispute was sovereign authority over property, something far different than what was at stake in Lee, Tindal, and Treasure Salvors. Given the conceptions of the majority, cases like Lee, Tindal, and Treasure Salvors had very little to offer in Coeur d'Alene. The existential category for Coeur d'Alene was probably the same as for state bond disputes in the 1800s. Perhaps fittingly, given the highly charged political aspects of Coeur d'Alene, the denial of the Tribe's Ex Parte Young action heightens the role of a political branch of government. The United States has chosen to sue in federal court on behalf of the Tribe, a political decision made by the executive branch. ${ }^{195}$

Although I have made a great deal of certain substantive existential categories for sovereign immunity cases, perhaps the larger lesson is one of method. Professor Jaffe's approach toward sovereign immunity cases recognized that as a practical matter, cases were existing in certain categories distinct from any over-arching analytic principle. Although he did not analyze any cases like Coeur d'Alene, where state sovereignty was pitted against Indian sovereignty, Professor Jaffe's approach demonstrated how special cases were treated specially. When I say that Coeur d'Alene falls in a category like the state bond cases, it is more a judgment of the special nature of the Coeur d'Alene case and not that Professor Jaffe outlined categories which have an especially snug fit around Coeur d'Alene. Sovereign immunity cases come in many shapes and sizes, which Professor Jaffe recognized and believed the Court was recognizing as well. Unfortunately, it is the one-size-fits-all doctrine of Ex Parte Young and Edelman that leaves the current Court in a doctrinal straitjacket.

\section{$\mathrm{V}$ \\ Some Considerations for Ex Parte Young from Coeur d'Alene, PROFESSOR JAFFE, AND PROFESSOR SCALIA}

Although it seems absurd to think that all Ex Parte Young cases should be implicated by a unique case like Coeur d'Alene, Justice Kennedy was prepared to view Coeur d'Alene as an invitation to reformulate Ex Parte Young. Some of Justice Kennedy's ideas would move Ex Parte Young considerations closer to an explicit cognizance of the legal traditions identified by Professor Jaffe and are worth examining. Also worthy of examination are the reasons why Justices O'Connor, Scalia, and Thomas disapproved of Justice Kennedy's approach toward Ex Parte Young. Justice O'Connor and company may have genuinely disliked Justice Kennedy's vague balancing test; they may have had

195. See supra note 48. 
more fundamental objections to Justice Kennedy's conception of the Eleventh Amendment as merely providing the States with a forum choice; they may have had other reasons.

Whatever the differences between majority members in Coeur d'Alene, Professor Jaffe and Professor Scalia would likely advise the Court to consider compartmentalizing its officer suit doctrines, from the bottom up, using existential categories. As it stands now, the Court and commentators reason from the top down, beginning with generalized principles applicable to all ongoing violations of federal law. As a result, too much doctrine is at risk for confusion or distortion in any particular case. $^{196}$

\section{A. Justice Kennedy Reformulated Ex Parte Young in Line with Recognizable Existential Categories}

Justice Kennedy proposed that before the Court allow Ex Parte Young actions in federal court when there is an available state forum, the Court should balance federal and state interests. ${ }^{197}$ His citing of Milliken (II) pointed out perfectly how the nature and importance of the federal interests at stake might change the sovereign immunity calculus. Professor Jaffe concluded that "[w] here the enforcement of state policy threatens federal instrumentalities or federal programs or is in defiance of constitutional inhibitions... Osborn and Ex Parte Young are the prototypes."198 Justice Kennedy was explicitly recognizing a legal tradition identified by Professor Jaffe. Similarly, when Justice Kennedy proposed that Ex Parte Young "reflect the real interests of States," his statement resembled Professor Jaffe's conclusion that officer suits affecting the "general powers and functions of the goverument," like the enforcement of a large bond issue, would likely meet a bar of immunity. ${ }^{199}$ As demonstrated by Milliken (II) and Coeur d'Alene, the Court will uphold or deny Ex Parte Young actions depending on whether the action fits into the overwhelming-federal-interest category or the severely-threatened-state-interest category, even though the test for relief is the same in both cases.

196. See Scalia, supra note 1, at 918-19 (discussing top-down and bottom-up reasoning and the risks of distortion for nonstatutory review of certain federal administrative action when starting from broad levels of generality).

197. See Idaho v. Coeur d'Alene, 117 S. Ct. 2028, 2039 (1997).

198. Jaffe, supra note 14, at 29.

199. Id. at 28 . 


\section{B. Why Justices O'Connor, Scalia, and Thomas Did Not Join Justice Kennedy's Reformulation of Ex Parte Young}

Without engaging in rampant speculation, there are two likely reasons why Justices $O^{\prime}$ Connor, Scalia and Thomas did not join Justice Kennedy's reformulation of Ex Parte Young. First, they may have been genuinely skeptical about Justice Kennedy's balancing test. Second, they may have disagreed fundamentally with Justice Kennedy's view of the Eleventh Amendment as merely providing the States with a forum choice. ${ }^{200}$

Justice O'Connor accused Justice Kennedy of replacing a "straightforward inquiry" with a "vague balancing test."201 Justice Scalia, in particular, has no fondness for balancing tests. ${ }^{202}$ Justice Kennedy's proposed test would certainly complicate a threshold jurisdictional inquiry, but Justice Kennedy can rightfully claim that his balancing test makes more "visible and accountable the inevitable weighing process that [retrospective/prospective line-drawing] obscures." ${ }^{203}$ Justice Kennedy might also rightfully claim that he is only usimg a balancing test to give the Court "further exposure to the problem" in the hope that a new "clear line of demarcation" can be set. ${ }^{204}$ Clearly the Court is willing to undertake further exposure to sovereign immunity questions because the Court has been granting certiorari in cases like Coeur d'Alene and Seminole Tribe and upholding sovereign immunity. Whether the Court wants to settle sovereign immunity questions with balancing tests or bright-lines may still be up in the air. ${ }^{205}$

200. A third reason may simply have been a lack of fair warning. The case was argued in October but did not come down until June 23, 1997, and Justice O'Connor remarked in her opinion that the "parties have not briefed whether such a shift in the Young doctrine is warranted." $117 \mathrm{~S} . \mathrm{Ct}$. at 2045. A fourth reason is that Justice Kennedy simply went too far in limiting federal court jurisdiction.

201. 117 S. Ct. at 2047 (opinion of O'Connor, J.).

202. Justice Scalia elsewhere in the 1996-97 Term showed his disdain for balancing. In Printz $v$. United States, 117 S. C. 2365 (1997), Justice Scalia twice proclaimed the impropriety of balancing interests in determining whether Congress may force state executive officials to administer federal programs. See id. at 2383-84; see generally Antonin Scalia, The Rule of Law as a Law of Rules, 56 U. CHI. L. REv. 1175 (1989).

203. Sullivan, supra note 136 , at 67.

204. See Frank H. Easterbrook, Ways of Criticizing the Court, 95 HaRv. L. Rev. 802, 810 (1982); Coeur d'Alene, 117 S. Ct. at 2039 (opinion of Kennedy, J.) ("There is no reason why the [Ex Parte Youngl line cannot be drawn to refiect the real interests of States consistent with the clarity and certainty appropriate to the Eleventh Amendment's jursidictional inquiry.").

205. Professors Soifer and MacGill argued that "[f]ederal and state powers ebb and flow relative to one another in response to messy and mutable social, pohitical, and economic conditions. They cannot be contained by a formula, least of all a rigid one." Aviam Soifer \& H.C. MacGill, The Younger Doctrine: Reconstructing Reconstruction, 55 Tex. L. Rev. 1141, 1168 (1977). The approach of Justice Kennedy and Chief Justice Rehnquist in Coeur d'Alene may have been a move in this direction, or it may have simply been a first step toward a new bright line demarcation. In the same term in Printz v. United States, Justice O'Connor, the fifth vote for a 5-4 majority, wrote a concurring opinion preserving the possibility of balancing federal versus state interests when 
Justice $\mathrm{O}^{\prime}$ Connor and company may have simply rejected creating the complications of a case-by-case balancing approach in Coeur d'Alene, but they might be protesting too much. Justice Kennedy's approach in Coeur d'Alene is a more accurate reflection of how the Court is reaching its results in sovereign immunity cases, whether or not a majority wants to admit it. Justice Kennedy's approach may also more accurately reflect the Court's continued desire to tinker with sovereign immunity doctrine and federalism more generally.

Justice O'Connor and company, however, may have rejected Justice Kennedy's view that in Coeur d'Alene the Eleventh Amendment merely provided the state officers with a forum choice. Although Justice Kennedy gathered a majority for his statement that "the Young exception must reflect a proper understanding of its role in our federal system and respect for state courts, ${ }^{206}$ Justice Kennedy's analysis of how Ex Parte Young should operate when a state forum is available did not gather a majority. Justice Kennedy placed particular emphasis on the availability of Idaho state courts which were "open to hear and determine the case."207 Justice Kennedy's position begs the question whether Coeur d'Alene would have been decided differently if Idaho had refused to appear in its own courts. An answer to that hypothetical depends on whether state sovereign immunity merely bars an Ex Parte Young action in a federal court or whether such immunity is a complete bar to a particular type of action in any court. ${ }^{208}$ Such questions are beyond the scope of this Comment. ${ }^{209}$ It is possible that the members of the majority in Coeur d'Alene cannot agree among themselves on the full nature of Eleventh Amendment immunity, although they can agree on results.

\section{The Need to Compartmentalize Ex Parte Young Doctrine}

Even if a majority of the Court could not agree on a reformulation of Ex Parte Young in Coeur d'Alene, it would seem that something

Congress orders state executive officers to perform "purely ministerial reporting requirements." 117 S. C. at 2385 (O'Connor, J., concurring). Justice Scalia had written for the majority in Printz, including Justice Kennedy and Chief Justice Rehnquist, that "no case-by-case weighing of the burdens or benefits is necessary." Id. at 2384.

206. Idaho v. Coeur d'Alene, 117 S. Ct. 2028, 2034 (1997).

207. Id. at 2043.

208. See generally Vazquez, supra note 46 , at 1683 .

209. One small hint that Justices O'Connor, Scalia, and Kennedy may not agree on such issues can be fonnd in Hilton v. South Carolina Pub. Rys Comm'n, 502 U.S. 197 (1991). Justice Kennedy wrote for the majority and through a tangled web of previous decisions concluded that although various Eleventh Amendment-driven plain statement doctrines did not provide for a federal action in federal court, the same action could still be pursued in state court. Justice O'Connor, writing for herself and Justice Scalia, dissented and called Justice Kennedy's result a "remarkable anomaly" in that it made state courts the "exclusive avenue for obtaining recovery under a federal statute." Id. at 210 (emphasis added). 
needs to change. It is simply too doctrinally hazardous to have the retrospective/prospective-relief inquiry attempting to be all things to all ongoing violations of federal law by state officers. Coeur d'Alene exemplifies this hazard. A unique case gives and takes its principles to and from all sovereign immunity cases. Professor Jaffe and Professor Scalia might advise the Court to compartmentalize Ex Parte Young doctrine based on existential categories that have developed in our legal tradition. With some sort of categories in place, Coeur d'Alene would look more like the unique case that it is, and the Court could address it without risking confusion or distortion for all officer suits. This is not to say that the Court must create existential categories. Some categories already exist and are driving decisions like Coeur d'Alene. Compartmentalizing Ex Parte Young doctrine can start with Professor Jaffe's insights on our legal tradition with regard to sovereign immunity. Although some scholars find state sovereign immunity "deplorable"210 and a "rotten idea" 111 based on the Eleventh Amendment being an "embarrassment to the United States's aspiration to be a government of laws and not men,"212 if the prevailing decisions and rationales can be made more coherent at least the Court's actions will be more rule-like.

\section{CoNCLUSION}

Coeur d'Alene is a unique case presenting unique problems. We cannot discern precisely what the Court was thinking in its fractured resolution of the case, but if we start with what Professor Scalia called "existential categories," fact-driven conceptual patterns, as opposed to general analytic principles regarding officer suits and sovereign immunity, the Court's decision makes more sense. Perhaps more importantly, the Court's apparent frustration with the analytic frameworks of the $E x$ Parte Young doctrine, and eventual disregard for the frameworks, seem justified. Professor Jaffe offered numerous insights on the legal traditions of sovereign immunity that illuminate how the Court may have conceived of the dispute in Coeur d'Alene and why the Court upheld sovereign immunity. The Court might approach sovereign immunity cases more like Professor Jaffe approached sovereign immunity cases: Look to the legal traditions and possible existential categories instead of attempting to forge or abide by abstract principles that are all things to all ongoing violations of federal law by state officers. With some categories in place or at least an approach that recognizes that all ongoing violations of federal law by state officers are not the same, Ex

210. Currie, supra note 19 , at 548.

211. Id.

212. Vazquez, supra note 46 , at 1685. 
Parte Young cases like Coeur d'Alene might not be such doctrinally risky ventures. 
CALIFORNIA LAW REVIEW 